\title{
ARTICLE
}

\section{Substitutes for Insider Trading}

\author{
Ian Ayres* \& Joe Bankman**
}
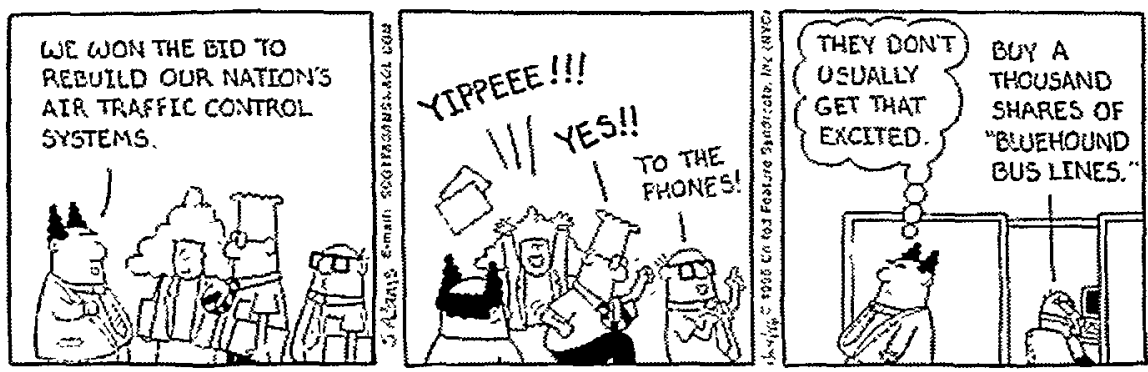

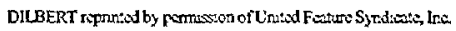

When insider trading prohibitions limit the ability of insiders (or of a corporation itself) to use material nonpublic information to trade a particular firm's stock, there may be incentive to use the information to trade instead in the stock of that firm's rivals, suppliers, customers, or the manufacturers of complementary products. We refer to this form of trading as trading in stock substitutes. Stock substitute trading by a firm is legal. In many circumstances, substitute trading by employees is also legal. Trading in stock substitutes may be quite profitable, and there is anecdotal evidence that employees often engage in such trading. Our analysis suggests that substitute trading is less socially desirable than traditional insider trading. We recommend a set of disclosure rules designed to clarify existing law and provide information on the extent of stock substitute trading. We also discuss possible changes in the law that might limit inefficient trading in stock substitutes.

* William K. Townsend Professor, Yale Law School. Email: ian.ayres@yale.edu.

$\because \div$ Ralph M. Parsons Professor of Law and Business, Stanford University. Email: jbankman@stanford.edu. Larry Stubsky, Fred Vars, Steve Choi, Donald C. Langevoort, Jesse Fried, Roberto Romano, Henry Hansmann, Alan Schwartz, Al Klevorick, Arturo Bris, Karl Groskaufmanis, Barry Adler, Benjamin Hance, and participants at Columbia, Stanford, American, University of Pennsylvania, and University of Southern California law school workshops provided helpful comments. Ben Hance and Steve Kwok provided particularly valuable research assistance and comments. 
INTRODUCTION

I. THE ECONOMICS OF TRADING IN STOCK SUBSTITUTES..................................... 241

A. Information and Stock Correlations ................................................... 241

B. The Mechanics of Trading in Stock Substitutes .................................... 246

II. IS SUBSTITUTE TRADING CURRENTLY LEGAL?............................................... 251

A. Liability Under Traditional Theories of Section 10b-5 ....................... 252

B. The Misappropriation Doctrine............................................................ 254

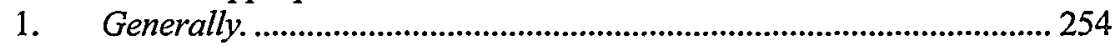

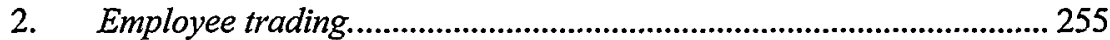

3. Employer trading.................................................................................. 259

C. Other Federal Limitations on Trading in Stock Substitutes ............... 260

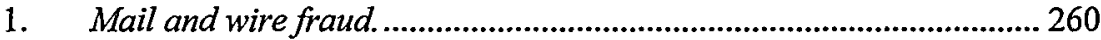

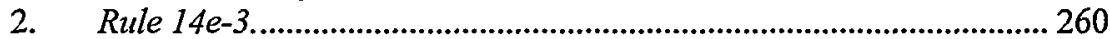

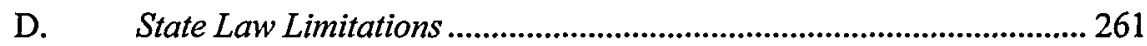

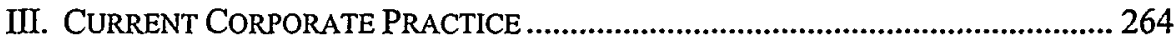

IV. DESIRABILITY OF TRADING IN STOCK SUBSTITUTES ....................................... 267

A. Current Thinking on the Desirability of Insider Trading .................... 267

B. Hypothetical Auctions and the Quasi-Dominance of Firm vs. Managerial Trading ...................................................................................... 270

C. Desirability of Trading in Stock Substitutes ......................................... 275

1. The externalization of costs (and benefits). ........................................... 276

2. Trading by firms rather than employees.............................................. 279

3. Trading on privity substitutes (i.e. customers, suppliers, or joint

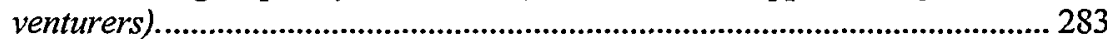

4. Trading on non-privity substitutes (i.e. rivals and complementors)... 285

V. POLICY RECOMMENDATIONS....................................................................... 285

A. Defining Stock Substitutes ................................................................ 285

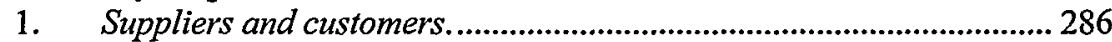

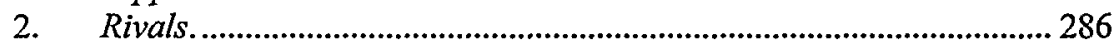

3. A quantitative definition of stock substitutions.................................... 287

4. Other possibilities................................................................................ 288

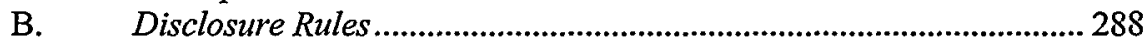

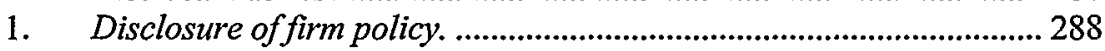

2. Disclosure of trades........................................................................... 289

3. Disclosure of the implicit value of stock trading as executive compensation................................................................................................. 289

C. Changes in Substantive Law........................................................... 290

D. Other Possible Changes in Substantive Law ....................................... 291

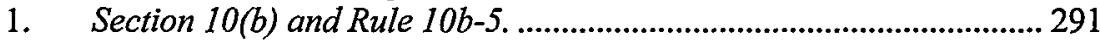

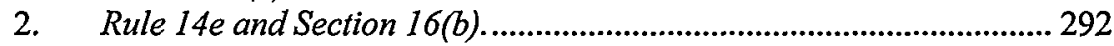

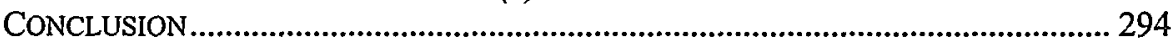

\section{INTRODUCTION}

The securities laws clearly prohibit an executive from using nonpublic information about her company to profit from trades in the securities of that 
company. But suppose the executive uses the same nonpublic information to profit from trading in the stock of another company. Suppose, for example, that an executive of Intel learns that her company will report higher than expected earnings because of higher than expected chip demand. Can she profit from this knowledge by purchasing the stock of other companies that she knows are likely to benefit from the same increased demand? For example, can she purchase the market basket of companies (other than Intel) that compose the Philadelphia Semiconductor Index? The stock of personal computer manufacturers or retailers? The stock of software companies whose products are complementary with personal computer sales? Under the right circumstances, such companies can all be thought of as stock substitutes for Intel. A strategy of trading in stock substitutes with nonpublic knowledge of Intel earnings will produce a supranormal return.

Profits from such trading can be substantial. To cite but one example, Intel on November 10, 1998 did in fact report higher than expected quarterly demand (by $4 \%$ or so) for its microprocessor. On the day following the announcement, Intel's stock rose about $5 \%$, for a rise in market value of about $\$ 7$ billion. Intel's announcement was interpreted in the financial press as indicating strong demand for personal computers generally. The stock of other companies in that industry, and the market baskets of stocks in that industry (such as the Philadelphia Semiconductor Index), rose between $2.5 \%$ and $5 \%$. The stock of Intel's downstream customer, Compaq, rose $4 \%$, a dollar rise of over $\$ 2$ billion in market value. The price of short-term call options in Compaq increased dramatically. ${ }^{1}$ Analysis linked the increase in stock value of Compaq and other companies to the increased demand for PCs, as suggested by Intel's strong earnings report. 2

In this Article, we will focus on circumstances where an informed insider (or a corporation itself) could trade profitably in its own stock but for Securities and Exchange Commission Rule $10 \mathrm{~b}-5$ ' $\mathrm{s}^{3}$ traditional prohibition on insider trading. To avoid a clear-cut Rule $10 \mathrm{~b}-5$ violation, the insider might instead want to substitute trade in other stocks whose price will be predictably affected by the same information. 4 Such substitute trading could potentially take a

1. For example, November call option contracts to buy Compaq at $\$ 33$ rose $19 \%$ on that day. See infra Part I.B(analyzing change in larger basket of option contracts). But see Steven M. Sears, Intel Corp. 's Options Get a Shot in the Arm from Forecast of Better-ThanExpected Profit, WALL ST. J., Nov. 12, 1998, at C13 (reporting that Compaq's increase also due, in part, to announcement that it would market computers directly to consumers).

2. Intel Shares Rise 6.3\% to a Record, PORTLAND OREgONIAN, Nov. 12, 1998, at B3.

3. 17 C.F.R. $\$ 240.10 b 5-1$ (2000).

4. At other times, an employee (or a firm) itself will come upon a piece of nonpublic information, which, while not related to its own stock, creates a profitable trading opportunity in other companies' stock. While some of the Article's analysis is relevant to such cross trades (see infra Part II.C.2), such cross trading is not literally a substitute for prohibited insider trading. Informationally driven nonsubstitute trading instead raises issues of when we should allow trading on the basis of nonpublic information (as is discussed in the 
variety of forms. Particular types of information will cause the price of a stock substitute to predictably move in the opposite direction of the price of one's own company. Information that would make an insider want to buy shares of his or her own company will sometimes induce the insider to want to sell another company's shares. For example, if an insider of Genentech realizes that Genentech is likely to win the race in cloning a particularly useful monoclonal antibody, then selling rivals' stock short may be a close substitute for buying Genentech shares long.

The impetus for substitute trading will not be limited to corporations that sell substitute products. Supranormal returns may also be realized in trades on the stock of upstream suppliers and downstream customers. For example, an executive of Ford Motor Company may hear from her engineers nonpublic information about an assembly-line robotic device tested by Ford but manufactured by another company. Or substitute trading in the stock of complementary products may become profitable. A corporation, rather than its employees, may trade in stock substitutes. In the above examples, supranormal profits may be available to Intel, Genentech, and Ford.

Substitute trading, if legal, could threaten to undermine the effectiveness of insider trading prohibitions generally. Yet legal scholarship has not focused squarely on the problem. 5 In Part I of this Article, we examine the economics

section on Rule 14e). See id.

5. Trading in stock substitutes is mentioned in passing in a number of thoughtful legal articles or reports on insider trading. See AMERICAN LAW INSTITUTE, FEDERAL SECURITIES CODE $\$ 1603$ (1980) ("It would be convenient to have a new category of 'quasi-insider' that would cover people like (i) judges' clerks who trade on information in published opinions ... and perhaps (iv) persons who are about to give profitable supply contracts to corporations with which they are not otherwise connected.... But all this does not lend itself to definition. It is difficult in the abstract to opine even on illustrative cases."); see also Dennis W. Carlton \& Daniel R. Fischel, The Regulation of Insider Trading, 35 STAN. L. REV. 857,874 (1983) (observing that a key supplier of a firm could theoretically engage in trading based on inside information just as a key executive within the firm could, and that while the supplier's actions are not illegal under insider trading laws, the supplier's action nonetheless creates the same moral hazard that the executive's action creates); Arthur Fleischer, Jr., Robert H. Mundheim \& John C. Murphy, Jr., An Initial Inquiry into the Responsibility to Disclose Market Information, 121 U. PA. L. REv. 798, 815-17 (1973) (discussing the faimess under current securities law of an employee using nonpublic information to purchase stock in a company that the employee's firm is considering buying a controlling number of shares of). As two economists have written:

Though there is a large literature on the economic and legal aspects of insider trading, this literature suffers from a serious omission: almost all attention has been focused on trading by officers and directors of one corporation in that corporation's publicly traded securities. [But] another likely type of insider trading is by officers and directors of one corporation (Corporation A) in another corporation's (Corporation B) securities.

Robert G. Hansen \& John R. Lott, Jr., Profiting from Induced Changes in Competitors' Market Values: The Case of Entry and Entry Deterrence, 43 J. INDus. ECON. 261, 261 (1995) (footnote omitted); see also Nicholas L. Georgakopoulos, Classical and Cross Insider Trading: Variations on the Theme of Rule 10b-5, 28 AM. Bus. L.J. 109, 110-11 (1990) (arguing that cross trading is more undesirable than classical insider trading); Nicholas $\mathrm{L}$. Georgakopoulos, Insider Trading as a Transactional Cost: A Market Microstructure 
of trading in stock substitutes. We summarize the literature on stock correlations and review event studies that measure the effect that a public announcement by one company has on other companies in the same industry. We also discuss the "mechanics" of trading in stock substitutes to assess how profitable such trading might be. A representative issue covered is how much stock a trader could buy, as a percentage of daily volume or market capitalization, without so moving price as to offset any informational advantage.

In Part II, we examine the legality of trading in stock substitutes. Section 10(b) of the 1934 Securities Exchange Act ${ }^{6}$ has traditionally been interpreted to prohibit an insider from using material nonpublic information to trade in her own company's stock. An insider for this purpose would include the company itself. Under this traditional interpretation, an insider could legally trade in another company's stock. The rationale for this is that the insider is not a fiduciary of the company whose stock she is trading and therefore owes no duty to its shareholders. The reach of Section 10(b) has been extended under the socalled "misappropriation" doctrine. Under this doctrine, a fiduciary who, in violation of the confidence of her principal, uses information gleaned from her role to profit from securities trading has violated Section 10(b). The misappropriation doctrine requires a fiduciary relationship between the trader and the source of the information; it does not require a fiduciary relationship between the trader and the shareholder on the losing end of the trade.

How would the misappropriation doctrine affect trading in stock substitutes? An employee is a fiduciary of her employer. If a company explicitly prohibits its employees from using nonpublic information to trade in another company's stock, an employee who violates that prohibition will violate Section $10(\mathrm{~b})$. If, on the other hand, a company explicitly permits its employees to trade in another company's stock, an employee who trades will not violate the confidence of her employer and will not run afoul of Section 10(b). The application of the doctrine in the (typical) case in which the employment contract is silent as to the permissibility of trading in stock substitutes is somewhat unclear; security lawyers would advise employees in this situation not to trade. Significantly, the misappropriation doctrine will not limit a company's use of its own nonpublic information to trade in another company's stock. Such trading does not violate the confidence of any fiduciary.

Part III discusses what can be gleaned about current corporate practiceboth concerning corporate policies regarding substitute trading and the extent to which such informationally-driven trading occurs. Some companies-

Justification and Optimization of Insider Trading Regulation, 26 CONN. L. REV. 1, 14-16 (1993) (observing that trades by informed noninsiders does not give rise to insider trading liability).

6. 15 U.S.C. $\$ 78 \mathrm{j}(\mathrm{b})(2000)$. 
particularly in the securities industry-expressly prohibit their employees from trading in stock substitutes. We have also uncovered a few examples of companies that in the past have given employees explicit permission to trade in stock substitutes. But most employment contracts are silent as to whether such trading is permitted or prohibited. This finding is roughly consistent with what we would expect. Stock substitute trading offers a form of compensation paid for largely by the shareholders of another company; an employer who attempts to limit this trading by contract would face difficult line-drawing issues and run the risk of imposing criminal penalties on employees who approach those lines. It is difficult to get even good anecdotal data on the degree of trading in stock substitutes. Our best guess is that low-level employee trading is common, but that large-scale corporate trading does not occur.

Part IV examines the desirability of trading in stock substitutes. We focus on efficiency effects and first review the existing debate over insider trading, that is, trading by a company in its own stock or trading by an employee in her company's stock. (To avoid confusion, we will use the term "insider trading" to describe this form of trading, and the term "trading in stock substitutes" to describe a company or executive trading in another company's stock.) Opponents of Section 10(b) liability argue that insider trading profits are best viewed as a potential form of compensation to executives; if insider trading were legalized, shareholder losses on trades with insiders would be offset by shareholder gains from lower explicit pay to insiders. Insider trading would produce a social good: more accurate stock pricing. In any event, since losses from insider trading are internalized to the company and its shareholders, the decision whether to permit such trading ought to be left to the company. Supporters of the present law argue that insider trading distorts employee incentives. We extend the analysis by pointing out another problem with employee insider trading: It inefficiently ties the purchase of executive services to the sale of trading rights. We conclude that employee insider trading is presumptively inefficient. However, insider trading carried out by a corporation, rather than its employees, may well be efficient.

We agree with a primary contention of opponents of the present law: Efficiency gains and losses are internalized to each company, and focusing at least on efficiency-related goals, the present no-trade rule might be made elective, rather than mandatory. However, because a corporation's decision to let its manager trade on material nonpublic fiduciary information is a quintessentially self-interested transaction, the decision should be subjected to the heightened procedural and substantive scrutiny that arises under the duty of loyalty standard.

Trading in stock substitutes raises many of the same costs and benefits issues as direct insider trading. Trading may distort incentives but lead to more accurate stock prices; shareholders gain from lower explicit pay but lose on trades. However, gains and losses in stock substitute trading are not internalized by the company (and ultimately, the shareholders of the company) 
whose employees trade. Significantly, gains from trades accrue to the company that trades, or whose employees trade, while losses are realized by shareholders of the company whose stock is traded. There can be no presumption, therefore, that a "hands-off" approach will result in an efficient amount of trading. Under reasonable assumptions, there will be "too much" trading in stock substitutes.

Part V discusses changes in the law that might follow from our analysis. We recommend a set of disclosure rules that should clarify existing law, and provide information to investors and policymakers. We outline substantive changes that would prevent inefficient trading in stock substitutes. Finally, we discuss the implications of our analysis on related securities law issues.

\section{THE ECONOMICS OF TRAdING IN StOCK SubSTITUTES}

\section{A. Information and Stock Correlations}

To get a better handle on the potential scope of substitute trades, it is useful to more specifically define what types of corporate relationships can produce profitable stock substitute trading opportunities. Vertically, most firms have upstream suppliers and downstream customers. Horizontally, most firms have competitors and "complementors." 7 All four types of firms can potentially be stock substitutes. And in each case, different types of inside information could produce positive or negative correlations between the insider's stock and the substitute stock. For example, inside information that the demand for PCs is stronger than expected would create a positive correlation between Intel's price and the price of one its downstream customers; but inside information that there would soon be additional entry downstream ${ }^{\S}$ might increase Intel's bargain power vis-à-vis its downstream customers and thereby create negative correlation between Intel's price and the price of its downstream customers. These examples suggest that sometimes buying a customer's stock and sometimes selling a customer's stock will be a substitute trade for buying a company's own stock. Examples can readily be provided with regard to each of the other three types of stock (suppliers, competitors, and complementors) to show that inside information will sometimes suggest positive or negative correlations in expected future stock movements. ${ }^{9}$

7. The term "complementors" is taken from ADAM M. BRANDENBURGER \& BARRY J. NALEBUFF, CO-OPETITION (1996). A complementor is a company that sells a complementary product. Complementors for Intel would include to varying degrees both software (e.g., Microsoft) and hardware (e.g., Dell) manufacturers. As Brandenburg and Nalebuff stress, however, increasingly a firm that is a complementor in one context may be a customer, supplier, or competitor in other contexts. Id. at 28-32.

8. Imagine the new entrant first privately approached Intel to secure chip supply.

9. For example, with regard to a competitor, an insider may have nonpublic information that industry demand exceeds expectations or nonpublic information that its 
The fact that we as outsiders tend to see technology stocks (for example, those included in the Philadelphia Semiconductor Index) move together understates therefore the potential to use substitute trading to circumvent the insider trading prohibition. From an insider's perspective, the predictable correlations-at times positive, at times negative-will be much stronger than what informationally challenged outsiders perceive as an average positive correlation. We define "trading in stock substitutes" to encompass any trades in these four types of firms that are substitutes for what, absent insider trading prohibitions, would be a profitable opportunity to trade in your own stock.

Indeed, substitute trading includes any information-driven transaction where the informed trader buys or sells a particular security as a second-best substitute for a prohibited transaction. For example:

An insider who would under Section 16(b) be forced to disgorge shortswing profits from trading in her own stock might instead trade in a rival's stock;

Or a lawyer who as a temporary insider under $10 \mathrm{~b}-5$ is prohibited from trading in a client's stock may instead want to trade in the stock of a complementary product;

Or an outsider who under Rule 14e-3 would be prohibited from purchasing stock in a company subject to a forthcoming tender offer might instead trade in a rival's stock.

Whenever a security law prohibits a form of information-driven trading, the objects of those regulations may have an incentive (unless constrained by law) to substitute a second-best trade.

There is abundant evidence that profitable opportunities for such secondbest substitute trading exists. For example, Robert Hansen and John Lott have noted the dramatic opportunities for profitable substitute trading when one firm decides to enter into another market. In 1974 Kodak decided to enter the instant camera market (which was until then occupied solely by Polaroid). Upon Kodak's announcement to enter, Polaroid stock fell from $795 / 8$ to 69 $1 / 2$, a total drop of $\$ 300$ million. 10

While there is no direct evidence that Kodak or its employees used this information to trade in Polaroid stock, there is at least indirect evidence that someone was trading in this information as the Chicago Board of Options Exchange restricted trading in Polaroid options four months earlier because of a buildup of uncovered short positions. ${ }^{11}$

Similar effects on rivals' prices can be found with regard to the announcement that new computer chips would be manufactured. Again, Hansen and Lott note:

product is about to become much better than its competitor's. The former information would create a positive correlation; the latter information would create a negative correlation.

10. Hansen \& Lott, supra note 5 , at 261 n.2.

11. See id. 
On April 23, 1993 Advanced Micro Devices announced that it began shipping clones of Intel Corporation's 486 microprocessor; Intel stock fell 6$3 / 4$ to 96 [representing a loss of approximately $\$ 32$ million] ... On April 14, 1994, IBM and Cyrix Corp. announced a pact whereby IBM would manufacture Cyrix MI microprocessors, which are also clones of Intel's 486 chip; Intel fell 3-1/4 to 60-1/2 [representing a loss of approximately $\$ 16$ million] .... On April 26, 1993, Motorola introduced the first versions of its Power PC chip, which competes with Intel's Pentium chip; Intel fell by 5-1/4 to $87-3 / 8$ [representing a loss of approximately $\$ 25$ million] ....12

In our initial example Intel might have used its knowledge of unexpectedly high chip demand to profitably trade in the stock of its customers or the manufacturers of complementary products. These examples suggest that a rival of Intel might have made money by selling Intel short before announcing the production of a new, competitive chip. But the size of the stock movements on the date of announcement suggests that corporations are not systematically exploiting these substitute trading opportunities-leaving billions of dollars of potential profits lying on the ground. ${ }^{13}$

While these Intel examples probably represent unexploited substitute trading opportunities, there is evidence that industrial mores have not always constrained businesses from trading in their rivals' stocks. The industrialist Jay Gould, for example, used substitute trading to profit on the predictable decline in value of a rival company's stock. When forming new telegraph companies to compete against the incumbent Western Union, he consistently sold short Western Union stock. ${ }^{14}$ And this same maxim-sell thy rival's stock short before entering-was used against Gould when a new steamship line began competing against his Pacific Mall company. 15

Dozens of event studies have documented how one firm's announcement concerning particular types of information consistently change other firms' stock prices. The majority of these studies concern "intra-industry" information flows-that is, how information about one firm affects the stock value of its industry rivals. For example, a 1996 study shows a positive correlation between one firm's dividends and its rival's stock returns. ${ }^{16}$ Unexpected dividend increases (decreases) for one firm led to increased

12. Id. at 262 n.2.

13. We will more directly assess whether and how such trading might be profitable. See infra Part I.B. Our "lying on the ground" reference is to the old joke in which two economists are walking down the street and one says, "Hey, there's \$20 lying on the ground." The other responds, "There couldn't be; someone would have already picked it up."

14. Juluus Grodinsky, Jay Gould, His Business Career 1867-1892, at 276 (1957); Matthew Josephson, The Robber Barons; The Great American Capitalists, 18611901, at 205 (1934); Hansen \& Lott, supra note 5, at 273.

15. H.A., Bye-the-Bye in Wall Street, WaLL ST. J., Sept. 17, 1925, at 3.

16. Michael Firth, Dividend Changes, Abnormal Returns and Intra-Industry Firm Valuations, 31 J. FIN. \& QUANTITATIVE ANALYSIS 189, 189, 210 (1996). 
(decreased) stock return for nonreporting rivals. 17 And a parallel result has been shown with regard to earnings disclosure. Announcements of unexpectedly increased (decreased) earnings tend to increase (decrease) the stock return of industrial competitors. 18

But theory suggests that many broad types of information might induce either positive or negative rival stock price reaction. For example, the announcement of unexpectedly high earnings could be good news for rivals if it was driven by an unexpectedly high general demand for the industry's goods, but it could be bad news for rivals if it was driven by the reporting firm's ability to shift demand away from its rivals or to unexpectedly reduce its costs relative to its rivals. And indeed one of the more nuanced analyses of stock market reaction to accounting information shows rivals' stock prices are sensitive to the underlying cause of increased earnings. If the increased earnings are caused by an unexpected increase in sales, this tends to be good news for the announcing firm's competitors; but if the increased earnings are caused by an unexpected decrease in costs, this tends to be bad news for the firm's rivals. ${ }^{19}$

Similar indeterminacy stories could be told with regard to the impact of several broad categories of announcements. The declaration of bankruptcy could be good news for rivals because they have one less competitor, or it could be bad news because it might indicate that the industry is in poorer health than was previously thought. The announcement of a horizontal merger could be good news for rivals because it may increase the chance of oligopolistic pricing, or it could be bad news for rivals because it may increase the chance of exclusionary practices. The announcement of a product recall might be good news for rivals because they may face weaker competition, or it might be bad news for rivals because it may signal their increased exposure to recalls or tort liability.

But in at least two of these examples (concerning bankruptcy and product recall), the best current empiricism suggests a positive correlation between the stock price of the announcing firm and the stock price of its rivals. When a firm declares bankruptcy, both its and its rivals' stock prices tend to fall. "A value-weighted portfolio of competitors' stock experiences a significant loss of $0.56 \%$ in the three days centered around the Chapter 11 announcement." 20 Empirically, the contagion effect outweighs the pro-competitive effect.

17. Id. at 189 .

18. George Foster, Intra-Industry Information Transfers Associated with Earnings Releases, 3 J. ACCT. \& ECON. 201, 201, 217-19(1981); see also Stephen P. Baginski, Intraindustry Information Transfers Associated with Management Forecasts of Earnings, 25 J. ACCT. RES. 196, 196, 213 (1987) (discussing the correlation between changes in disclosing firms' earnings expectations and stock valuation of firms in the same industry).

19. Gun-Ho Joh \& Chi-Wen Jevons Lee, Stock Price Response to Accounting Information in Oligopoly, 65 J. Bus. 451, 471 (1992).

20. Stephen P. Ferris, Narayanan Jayaraman \& Anil K. Makhija, The Response of 
Gregg Jarrell and Sam Peltzman have found a similar dominance of the contagion effect with regard to product recalls. ${ }^{21}$ Competitors of drug and auto firms with recalled products bear substantial losses. For example, the stock prices of rival drug manufacturers were found to suffer a statistically significant mean loss of over $1 \%$ in the two weeks surrounding a recall. ${ }^{22}$ A negative spillover effect was found with regard to automobile recalls as well. On average, competitors lost about two thirds as much as the recall company lost.

With regard to mergers, the general tendencies are much more contestable as an empirical matter. There is at least some empiricism, however, of a net negative correlation between the effects of government challenges to mergers - the announcement of a challenge tends to reduce the stock price of the merging company but increase the stock price of its rivals. ${ }^{23}$

The tendency for rivals' stock price on net to be positively or negatively correlated upon the announcement of these broad types of information-despite the theoretical ambiguity-has several implications for our analysis. First, there may be potential profits for even a relatively uninformed trader to engage in unnuanced trading if she only knows that a particular rival is about to declare bankruptcy. Second, as suggested above, there may be even larger potential profits for more nuanced trading. For while external social scientists may have difficulty identifying which circumstances are likely to give rise to positive or negative correlations, that will not be true for industry insiders. An insider who, for example, learns of an impending tire recall may have a much better idea of whether the stock prices of rival tire manufacturers are likely to increase or decrease on disclosure of the announcement than social scientists or uninformed traders. The existence of a general tendency suggests that profits from more nuanced trading may be even greater.

There are, however, circumstances where both theory and empiricism point more strongly toward a negative correlation. For example, one firm's unilateral increases in its $R \& D$ expenditures have been shown to reduce its rivals' stock

Competitors to Announcements of Bankruptcy: An Empirical Examination of Contagion and Competitive Effects, 3 J. CoRP. FIN. 367, 367 (1997); see also Larry H.P. Lang \& René M. Stulz, Contagion and Competitive Intra-Industry Effects of Bankruptcy Announcements: An Empirical Analysis, 32 J. FN. ECON. 45 (1992) (analyzing the degree to which bankruptcy announcements affect the equity value of the bankrupt firm's competitors).

21. Gregg Jarrell \& Sam Peltzman, The Impact of Product Recalls on the Wealth of Sellers, 93 J. POL. ECON. 512, 513 (1985).

22. See id. at 521.

23. See B. Epsen Eckbo, Horizontal Mergers, Collusion, and Stockholder Wealth, $11 \mathrm{~J}$. FiN. ECON. 241, 269 (1983). If credible, this result would suggest that merger challenges on average do not deter the creation of tighter oligopoly, but instead deter potential future exclusion (or at a minimum weaken the competitive position of the merging firms). But see Robert Stillman, Examining Antitrust Policy Towards Horizontal Mergers, 11 J. FIN. ECoN. 225,240 (1983) (finding almost no reaction by rivals); George Bittlingmayer \& Thomas W. Hazlett, DOS Kapital, Has Antitrust Action Against Microsoft Created Value in the Computer Industry (June 2, 1998) (unpublished manuscript on file with the author) (finding a positive correlation concerning antitrust suit against Microsoft). 
prices. ${ }^{24}$ And while not supported by event study analysis, it is fairly obvious that in zero-sum contests, such as litigation or patent racing, information about one firm's prospects would be negatively associated with the prospects of one's rival. Hence, in the Texaco-Penzoil dispute, information that Penzoil was about to win (lose) would suggest that it would be quite profitable to sell (buy) Texaco stock. Or information that Genentech was about win (lose) a particularly important patent race would suggest that it would be profitable to sell (buy) its rival's stock.

While event studies to date have focused on the "intra-industry" information flows ${ }^{25}$ - that is the impact of one firm's information on its rivals' stock prices-there is some evidence that suppliers' stock prices are positively associated with downstream retailers' sales announcements. ${ }^{26}$ For example, Olsen and Dietrich show that when downstream retailers (such as Sears or KMart) experienced a two-standard deviation change in their stock price (plus or minus) following an announcement of their recent sales figures, suppliers who sold more than $20 \%$ of their products to these retailers experienced parallel changes which were statistically significant. ${ }^{27}$ When the retailer's stock price went down more than two standard deviations, the supplier's stock price on average dropped $2.7 \%$ and when the retailer's stock price increased two standard deviations, the supplier's stock price increase $2.9 \% .28$ And of course such vertical information flows could move downstream as well. Our initial Intel example was in part a story about how a supplier's information about chip demand could be used to predict changes in the price of a customer (Compaq). Predictable correlations between upstream and downstream again raise the possibility of a profitable substitute trading strategy.

\section{B. The Mechanics of Trading in Stock Substitutes}

Exactly how profitable could substitute trading be? This section explores this question by analyzing our earlier Intel example. While only based on one

24. See Changqi Wu \& K.C. John Wei, Cooperative R\&D and the Value of the Firm, 13 REV. INDUS. ORG. 425, 425 (1998); Zaher Z. Zantout \& George P. Tsetsekos, The Wealth Effects of Announcements of R\&D Expenditure Increases, 17 J. FN. RES. 205, 205 (1994)).

25. See, e.g., Cliff Asness \& Michael Smirlock, A Note on REIT Bankruptcy and Intraindustry Information Transfers: An Empirical Analysis, 15 J. BANKING \& FIN. 1171 (1991).

26. See Nancy Beth Bronstein Boim, The Effects of Consolidated Edison's 1974 Dividend Omission Upon the Common Stock Returns of the Utilities Industry, 1 CHI. MBA 85 (1977); Michael G. Hertzel, The Effects of Stock Repurchases on Rival Firms, 46 J. FIN. 707, 707 (1991) (finding negative, but statistically weak, correlation between repurchase announcement and price of rival's stock).

27. Chris Olsen \& J. Richard Dietrich, Vertical Information Transfers: The Association Between Retailers' Sales Announcements and Suppliers'Secturity Returns, 23 J. ACCT. RES. 144,156 (1985).

28. See id. 
stylized example, our analysis confirms one's intuition that substitute trading can be extremely profitable. However, because of the relative illiquidity of the option markets, substitute trading is likely to be more attractive for employees than for firms themselves.

As discussed above, on November 10, 1998, Intel's reporting of higher than expected chip demand increased not only its own price but, unsurprisingly, the prices of many other related firms in the industry. For example, stocks on the Philadelphia Semiconductor Index increased 5.24\%, representing a combined increase in equity value of almost $\$ 4.5$ billion. 29 This increase in value represents the theoretical upper limit on the trading profits that might have been realized through substitute trading if an informed trader could somehow purchase $100 \%$ of the equity in these related firms without inducing a price increase (and then sell without inducing a price decrease).

Buying $100 \%$ of the shares without a market price response is, of course, impossible to do for both legal and nonlegal reasons. But what is possible? It is notoriously difficult to predict how quickly and how dramatically the market price will respond to abnormal increases in the demand or supply for a stock. To heuristically estimate how much a substitute trader might make in the real world, we analyzed three (relatively crude) assumptions about the potential market response. Our first approach-suggested to us by a successful and well-respected trader-assumes that a substitute trader can (and does) buy 20\% of the average daily trading volume of the stock for the ten days prior to the

29. The price movement in both dollar and percentage terms are reported in Table 1:

Table 1: Philadelphia Semiconductor Index November 10, 1998 Price Movements

\begin{tabular}{|c|c|c|c|c|}
\hline TICKER & Price on 10-Nov & $\begin{array}{c}\text { Change on Date } \\
\text { (percentage) }\end{array}$ & $\begin{array}{c}\text { Outstanding } \\
\text { Shares }\end{array}$ & $\begin{array}{c}\text { Theoretical } \\
\text { Upper Limit on } \\
\text { Profit }\end{array}$ \\
\hline AMAT & $\$ 35.63$ & $5.40 \%$ & $365,627,000$ & $703,374,941$ \\
\hline AMD & $\$ 26.50$ & $1.90 \%$ & $143,365,000$ & $72,184,278$ \\
\hline KLAC & $\$ 35.19$ & $4.30 \%$ & $86,873,000$ & $131,446,146$ \\
\hline LLTC & $\$ 63.50$ & $4.50 \%$ & $76,854,000$ & $219,610,305$ \\
\hline LSCC & $\$ 31.00$ & $6.60 \%$ & $23,558,000$ & $48,199,668$ \\
\hline MU & $\$ 44.25$ & $7.60 \%$ & $212,737,000$ & $715,434,531$ \\
\hline NSM & $\$ 12.94$ & $7.70 \%$ & $164,841,000$ & $164,218,890$ \\
\hline NVLS & $\$ 41.88$ & $7.00 \%$ & $33,835,000$ & $99,178,844$ \\
\hline RMBS & $\$ 68.13$ & $0.92 \%$ & $22,703,000$ & $14,229,105$ \\
\hline TXN & $\$ 63.88$ & $\$ .70 \%$ & $390,512,000$ & $2,170,123,998$ \\
\hline XLNX & $\$ 49.3 \$$ & $3.00 \%$ & $72,490,000$ & $107,375,813$ \\
\hline & & & & \\
\hline & $\begin{array}{c}\text { Average } \% \\
\text { Increase }\end{array}$ & $5.24 \%$ & $\begin{array}{c}\text { Total Price } \\
\text { Increase }\end{array}$ & $\$ 4,445,376,519$ \\
\hline
\end{tabular}


announcement without triggering a market response. Our second approachfollowing a finding of Myron Scholes ${ }^{30}$-assumes that a substitute trader can (and does) buy $2 \%$ of the outstanding shares without triggering a market response. And our third approach-following a finding of Laurie Bagwell ${ }^{1}$ assumes that the elasticity of the stock price with regard to increases in demand is $2.4 \%$ and that the substitute trader buys until the market prices rise to the informed trader's assessment of its true value. ${ }^{32}$ These approaches are still likely to overstate a trader's potential profits because each approach implicitly assumes that after Intel's announcement, the trader would be able to sell her holdings of the related firms' stock without inducing a price decrease. Still, given the severe limits of our knowledge about how market prices react to informed trading, we still believe this is a useful exercise to give us ballpark numbers of how much money might be made and how much liquidity a substitute trader would need to make it.

Table 2 reports the core estimates from our three approaches..$^{33}$

30. Myron S. Scholes, The Market For Securities: Substitution Versus Price Pressure and the Effects of Information on Share Prices 45 J. Bus. 179 (1972) (finding no selling pressure on price in study of secondary offerings).

31. Laurie Simon Bagwell, Shareholder Heterogeneity: Evidence and Implications, 81 AM. ECON. REV. 218 (1991) (arguing that earlier study of Dutch Auction stock repurchases shows inelasticity in the supply curve for purchases of large blocks of securities).

32. For the purposes of this last estimation, we assumed for heuristic simplicity that the substitute trader can accurately predict what the postannouncement price will be and trades before hand to the point where the announcement would have no effect on value.

33. The underlying estimates are reported here in Table 3:

\begin{tabular}{|c|c|c|c|c|c|c|}
\hline \multicolumn{7}{|c|}{ Table 3: Underlying Estimates of Potential Market Response } \\
\hline & \multicolumn{2}{|c|}{ Trader Assumption } & \multicolumn{2}{c|}{ Scholes Assumption } & \multicolumn{2}{c|}{ Bagwell Assumption } \\
\hline Stock & $\begin{array}{c}\text { Cost of } \\
\text { Accumulation }\end{array}$ & Profit & $\begin{array}{c}\text { Cost of } \\
\text { Accumulation }\end{array}$ & Profit & $\begin{array}{c}\text { Cost of } \\
\text { Accumulation }\end{array}$ & Profit \\
\hline AMAT & $\$ 520,703,621$ & $\$ 28,117,996$ & $\$ 260,509,238$ & $\$ 14,067,499$ & $\$ 1,688,099,859$ & $\$ 91,157,392$ \\
\hline AMD & $\$ 148,475,154$ & $\$ 2,821,028$ & $\$ 75,983,450$ & $\$ 1,443,686$ & $\$ 173,242,266$ & $\$ 3,291,603$ \\
\hline KLAC & $\$ 104,189,308$ & $\$ 5,948,950$ & $\$ 61,137,742$ & $\$ 2,62 \$, 923$ & $\$ 315,470,751$ & $\$ 13,565,242$ \\
\hline LLTC & $\$ 99,932,090$ & $\$ 8,115,151$ & $\$ 97,604,580$ & $\$ 4,392,206$ & $\$ 527,064,732$ & $\$ 23,717,913$ \\
\hline LSCC & $\$ 74,441,177$ & $\$ 2,398,530$ & $\$ 14,605,960$ & $\$ 963,993$ & $\$ 115,679,203$ & $\$ 7,634,827$ \\
\hline MU & $\$ 270,193,520$ & $\$ 29,311,639$ & $\$ 188,272,245$ & $\$ 14,308,691$ & $\$ 1,717,042,874$ & $\$ 130,495,258$ \\
\hline NSM & $\$ 141,657,702$ & $\$ 3,189,222$ & $\$ 42,654,257$ & $\$ 3,284,378$ & $\$ 394,125,336$ & $\$ 30,347,651$ \\
\hline NVLS & $\$ 39,637,788$ & $\$ 8,980,389$ & $\$ 28,336,813$ & $\$ 1,983,577$ & $\$ 238,029,225$ & $\$ 16,662,046$ \\
\hline RMBS & $\$ \$ 0,391,123$ & $\$ 1,203,227$ & $\$ 30,932,838$ & $\$ 284,582$ & $\$ 34,149,853$ & $\$ 314,179$ \\
\hline TXN & $\$ 374,061,976$ & $\$ 30,513,162$ & $\$ 498,879,080$ & $\$ 43,402,480$ & $\$ 5,208,297,595$ & $\$ 453,121,891$ \\
\hline XLNX & $\$ 258,487,051$ & $\$ 5,994,269$ & $\$ 71,583,875$ & $\$ 2,147,516$ & $\$ 257,701,950$ & $\$ 7,731,059$ \\
\hline & $\$ 2,112,170,510$ & $\$ 126,593,563$ & $\$ 1,370,500,077$ & $\$ 88,907,530$ & $\$ 10,668,903,645$ & $\$ 778,039,061$ \\
\hline Two WVek Return & $\mathbf{6 . 0} \%$ & & $6.5 \%$ & & $7.3 \%$ \\
\hline
\end{tabular}




\begin{tabular}{|c|c|c|c|c|c|c|}
\hline \multicolumn{7}{|c|}{ Table 2: Potential Profitability of Substitute Trading on } \\
Philadelphia Semiconductor Index \\
\hline Assumption & $\begin{array}{c}\text { Percent of } \\
\text { Outstanding } \\
\text { Shares } \\
\text { Accumulated }\end{array}$ & $\begin{array}{c}\text { Cost of } \\
\text { Accumulation }\end{array}$ & Dollar Profit & $\begin{array}{c}\text { Percent of } \\
\text { Potential } \\
\text { Profits }\end{array}$ & $\begin{array}{c}\text { Two- } \\
\text { Week } \\
\text { Return }\end{array}$ & $\begin{array}{c}\text { Annualized } \\
\text { Return }\end{array}$ \\
\hline Trader & $4.69 \%$ & $\$ 2,112,170,510$ & $\$ 126,593,563$ & $2.8 \%$ & $6.0 \%$ & $354.2 \%$ \\
\hline Scholes & $2.00 \%$ & $\$ 1,370,500,077$ & $\$ 88,907,530$ & $2.0 \%$ & $6.5 \%$ & $412.5 \%$ \\
\hline Bagwell & $12.57 \%$ & $\$ 10,668,903,645$ & $\$ 778,039,061$ & $17.5 \%$ & $7.3 \%$ & $523.5 \%$ \\
\hline
\end{tabular}

The results of this exercise teach us that the reaction of the stock market to substitute trading reduces the otherwise astronomical profits that Intel could earn from substitute trading. The trader and the Scholes assumptions have the trader earning 2-3\% of the $\$ 4.5$ billion dollar increase in the value of the related firms, while the Bagwell assumption does better but still captures less than $20 \%$ of the theoretical upper limit.

We also see that capturing these amounts requires large amounts of shortterm liquidity. The trader and Scholes assumptions require one or two billion dollars to be invested, while the more optimistic Bagwell scenario would require Intel to pony up more than $\$ 10$ billion. At the time of this announcement, Intel (one of the more liquid companies in America) only had about $\$ 2$ billion on hand. ${ }^{34}$ Given the way capital markets are currently organized, limited liquidity is likely to constrain a firm's ability to maximally exploit substitute trading opportunities. Investment bankers will provide bridge loans for takeover purposes, 35 but lending $\$ 10$ billion for two weeks to finance informed trading on a related firm is a service not currently offered by the investment banking community.

34. In its Balance Sheet for fiscal year 1998 , Intel reported having $\$ 2.038$ billion in cash. See INTEl CORP., SUMmary of 1998 BalANCE SHEET, available at http://www.pcquote.com/stocks/balance.php?ticker=INTC (last visited Sept. 10, 2001). Intel's revenues in 1998 were $\$ 26.273$ billion, with $\$ 14.129$ billion in profits, and a diluted earning per share of $\$ 1.73$. See id.

35. Bridge loans are short-term facilities often used to finance acquisitions until longerterm funding can be secured to replace it. A typical bridge loan will last 180 days and have a floating rate of 500 basis points above prime, with the possibility of a 180 day extension at an increased rate. See William D. Rifkin, Financing and Funding Mergers and Acquisitions, in 4 THE LIBRARY OF INVESTMENT BANKING: MERGERS, ACQUISITIONS, AND LEVERAGED BuYouTs S0, 85 (Robert Lawrence Kuhn ed., 1990). Typical bridge loans have principal amounts of several hundred million dollars, see, e.g., Paul M. Sherer, Banks Balk at Financing Merger Deals, WALL ST. J., Oct. 16, 1998, at A3, but bridge loans may extend into the billions, see, e.g, Paul M. Sherer, Goldman Sits on Bridge Loan After Maneuver Goes Awry, WAL, ST. J., May 22, 2000, at C1. 
These liquidity constraints may substantially dampen the interest of firms like Intel to engage in substitute trading. They earn an astronomical annualized return on their investment, but because they can only sustain returns for a short period on what to Intel may seem like a relatively small sum, it may not seem worthwhile to divert the firm's attention from the big issues (designing the next chip or marketing the current chip) in order to cash in on profits that are relatively small potatoes. ${ }^{36}$ Other factors may also militate against trading in stock substitutes. Earnings reaped through such trading are likely to be discounted by analysts as nonrecurring gains. And even a small probability of legal liability or that the investing community might look askance at such a source of profits might be sufficient to deter this rather modest one-time killing.

On the other hand, the gains in this example are large in absolute and percentage terms. And the example itself is built on a piece of information that had a relatively modest percentage effect on stock price. In a volatile and fastmoving sector such as technology, companies such as Intel will each year find themselves with information that is apt to have a larger effect on stock price, and therefore offer larger percentage gains from trading.

Substitute trading may seem even more attractive to employees. The key difference here is while options markets are not liquid enough to support large scale substitute trading by a firm, they may be liquid enough to allow an employee to make what from her perspective may be a sufficient amount of money without requiring an inordinate amount of capital. To explore this possibility, we estimated how much an employee of Intel might have been able to make by trading in the options market. We assume for these purposes that the employee purchases $2 \%$ of the average trading volume for ten successive days. As shown in Table 4, a two-week investment of approximately $\$ 250,000$ would have yielded a profit of about $\$ 53,500$-a $21 \%$ return and a $14,277.5 \%$ annualized return. Incorporating transaction costs into the calculation would reduce the profitability of the trade, but still leave the employee with high return on investment. Here, as with corporate trading, the return would be greater if we were considering information that had a greater than $4 \%$ effect on stock price.

36. See Julio J. Rotemberg \& Garth Saloner, Benefits of Narrow Business Strategies 84 AM. ECON. REV. 1330 (1994) (arguing that firms benefit by focusing employee's attention on improving profitability in core areas of business). 


\begin{tabular}{|c|c|c|c|c|c|c|c|}
\hline \multicolumn{7}{|c|}{ Table 4: Potential Profits from Substitute Trading on Options (Broker Assumption) } \\
\hline $\begin{array}{c}\text { Underlying } \\
\text { Asset }\end{array}$ & $\begin{array}{c}\text { Strike } \\
\text { Date }\end{array}$ & $\begin{array}{c}\text { Strike } \\
\text { Price }\end{array}$ & $\begin{array}{c}\text { Price on } \\
\text { Nov 10 }\end{array}$ & $\begin{array}{c}\text { Price Change } \\
\text { on Date }\end{array}$ & $\begin{array}{c}\text { Average } \\
\text { Trading } \\
\text { Volume }\end{array}$ & $\begin{array}{c}\text { Cost of } \\
\text { Accumulation }\end{array}$ & $\begin{array}{c}\text { Dollar } \\
\text { Profit }\end{array}$ \\
\hline Compaq & Nov & $\$ 30$ & $\$ 1.97$ & $\$(0.13)$ & 2920 & $\$ 11,496$ & $\$(730)$ \\
\hline & & $\$ 33$ & $\$ 0.66$ & $\$ 0.13$ & 2254 & $\$ 2,959$ & $\$ 564$ \\
\hline & & $\$ 35$ & $\$ 0.21$ & $\$-$ & 1261 & $\$ 526$ & $\$-$ \\
\hline Dell & Nov & $\$ 60$ & $\$ 7.69$ & $\$ 0.88$ & 3146 & $\$ 48,362$ & $\$ 5,505$ \\
\hline & & $\$ 65$ & $\$ 4.28$ & $\$ 1.00$ & 6729 & $\$ 57,614$ & $\$ 13,457$ \\
\hline & & $\$ 70$ & $\$ 2.86$ & $\$ 0.75$ & 7229 & $\$ 41,339$ & $\$ 10,843$ \\
\hline & & $\$ \$ 0$ & $\$ 0.17$ & $\$ 0.44$ & 918 & $\$ 306$ & $\$ 803$ \\
\hline & Dec & $\$ 65$ & $\$ 6.72$ & $\$ 1.25$ & 4320 & $\$ 58,051$ & $\$ 10,800$ \\
\hline & & $\$ 70$ & $\$ 4.50$ & $\$ 1.00$ & 1573 & $\$ 14,153$ & $\$ 3,145$ \\
\hline IBM & Nov & $\$ 155$ & $\$ 1.41$ & $\$ 1.75$ & 1315 & $\$ 3,698$ & $\$ 4,603$ \\
\hline Microsoft & Nov & $\$ 110$ & $\$ 2.02$ & $\$ 0.50$ & 3594 & $\$ 14,488$ & $\$ 3,594$ \\
\hline & & $\$ 115$ & $\$ 0.56$ & $\$ 0.38$ & 1340 & $\$ 1,50 \$$ & $\$ 1,005$ \\
\hline \multicolumn{2}{|c|}{ Totals } & & & & & $\$ 254,501$ & $\$ 53,589$ \\
\hline Two-week & & & & & & $21.1 \%$ \\
\hline Annualized & & & & & & $14277.5 \%$ \\
\hline
\end{tabular}

The much higher rate of return per dollar invested may make substitute trading more attractive to employees than employers. ${ }^{37}$ It is not surprising, therefore, that we find that currently, informationally informed substitute trading is carried out by employees rather than employers. ${ }^{38}$ Still there is a slight conundrum as to why firms do not engage in this practice more.

\section{IS SUBSTITUTE TRADING CURRENTLY LEGAL?}

This section examines the extent to which substitute trading is currently legal. We conclude that, in many cases at least, such trading is legal. Companies can trade substitutes without running afoul of Section 10(b). Companies can give their employees the right to trade in substitute stocks and can prohibit their employees from such trading. What about employees who work under labor contracts that are silent as to the permissibility of such

37. Other reasons may also make it more likely that employees rather than employers trade. As noted above, employers may believe that trading profits will be discounted by analysts or worry that trades will provoke an SEC reaction. Employees obviously are unaffected by analysts and may be relatively confident that their trades will go undetected. On the other hand, employer trading is clearly legal; not so for employee trading. See infra Part II at pp. 121-22.

38. See infra Part III at p. 132. 
trading? The answer here is unclear and may well depend on the facts and circumstances surrounding the particular case.

\section{A. Liability Under Traditional Theories of Section 10b-5}

Section 10(b) of the 1934 Securities Exchange Act provides in relevant part that

It shall be unlawful for any person ... (b) To use or employ, in connection with the purchase or sale of any security ... any manipulative or deceptive device... in contra-vention of such rules and regulations as the Commission may prescribe ... for the protection of investors. ${ }^{39}$

Securities and Exchange Commission Rule 10b-5 makes it unlawful "(a) To employ any device, scheme or artifice to defraud ... [or] (c) to engage in any act... which operates or would operate as a fraud or deceit upon any person." 40

Section $10(\mathrm{~b})$ and Rule $10 \mathrm{~b}-5$ may be enforced by a criminal or civil proceeding initiated by a U.S. Attorney, by a civil or administrative action initiated by the SEC, or, under some circumstances, by a civil action initiated by an injured party.

Section 10(b) has been applied to stock trading under two quite different theories. Under what is sometimes termed the "traditional" interpretation, Section 10(b) imposes a "disclose or abstain" rule on corporate insiders; such persons are prohibited from trading on material nonpublic information in the sale or purchase of securities. ${ }^{41}$ An "insider" for this purpose will include directors, officers, other employees of the company whose stock is being traded, and persons who receive tips from such persons. ${ }^{42}$ A company is also

39. 15 U.S.C. $\$ 78 \mathrm{j}(\mathrm{b})(2000)$.

40. 17 C.F.R. $\$ 240.10$ b-5 (2000).

41. The phrase "trading on" suggests that the information must play a causal role in the trade, and, as a corollary, that an insider can escape liability by establishing that she did not use the information in making her trading decision (i.e., that she would have traded anyway). The SEC has long urged the adoption of a "knowing possession" as opposed to "use" standard in Rule 10b-5. See Selective Disclosure and Insider Trading, Release Nos. 337881, 34-43154, IC-24599 [hereinafter Selective Disclosure and Insider Trading] (adopting Rule 10b5-1, 17 C.F.R. 240.10b5-1, which sets forth a possession standard with exceptions for sales made pursuant to agreements or written instructions executed prior to coming into possession of information and for certain sales of market-baskets of securities). Courts have split on the issue. Compare United States v. Teicher, 987 F.2d 112 (2d Cir. 1993) (adopting possession standard), with United States v. Smith, 155 F.3d 1051 (9th Cir. 1998), and SEC v. Adler, 137 F.3d 1325 (11th Cir. 1998) (both adopting use standard). In general, the debate does not have any special application or relevance to the topic of this Article. We take no position as to the merits of either party's position, and adopt the "use" terminology only because it leads to less awkward sentence structure.

42. See William K. S. Wang \& Marc I. Steinberg, Insider Trading $§ \S 5.2 .3,5.3$ 
considered an insider; it cannot trade on material nonpublic information in its own stock. ${ }^{43}$ With one exception discussed below, persons who do not fall into one of these four groups can profit on material nonpublic information without violating Rule $10 \mathrm{~b}-5$. That rule does not in general impose a "level playing field" by removing all sources of informational advantages a particular trader may have. An analyst or another trader who discovers material nonpublic information may use such information to her advantage. Under the traditional view, Section 10(b) only eliminates the advantage a fiduciary of a company may have, and then only to the extent the advantage is attributable to material, nonpublic information about her company, and is used in security transactions in her company's stock or options on that stock.

Thus, under the traditional view of $10(\mathrm{~b})$, a director of Intel could not take advantage of material nonpublic information about Intel to profit from trading in Intel stock. However, a director of Intel could use the same information to trade in Compaq stock. The director of Intel is not a fiduciary of Compaq and so owes no duty of loyalty to Compaq shareholders.

The scope of $10(\mathrm{~b})$ is enlarged somewhat by the so-called "temporary insider" doctrine. Under that doctrine, outsiders who are entrusted by a corporation with valuable information under conditions of confidentiality are treated as insiders of that corporation. ${ }^{44}$ Thus, an attorney in private practice becomes a temporary insider of a company that hires him. ${ }^{45}$ The same holds true for other advisers, such as accountants, management consultants, or investment banks. ${ }^{46}$ The scope of the temporary insider doctrine is somewhat unclear. It might extend to certain kinds of information gained through vertical supply relationships. Oracle employees who custom design a database for a retailer may become temporary insiders of that company; Ford employees who help design and test a piece of assembly-line manufacturing equipment may be

(1996 \& Supp. 2000) (defining "insider" and "tipee" liability).

43. Corporations are clearly subject to the 10 (b) liability for misleading statements, and it is commonly assumed that corporations would face 10(b) liability for trading on material nonpublic information. See DONald C. LANGEVOORT, 18 INSIDER TRading: Regulation, ENFORCEMENT \& PREVENTION § 3.02[1][d] (2001); WANG \& STEINBERG, supra note 42, at § 5.2.3.3.

44. As explained by the Supreme Court,

Under certain circumstances, such as where corporate information is revealed legitimately to an underwriter, accountant, lawyer, or consultant working for the corporation, these outsiders may become fiduciaries of the shareholders. The basis for recognizing this fiduciary duty is ... that [such persons] have entered into a special confidential relationship in the conduct of the business ... For such a duty to be imposed, however, the corporation must expect the outsider to keep the disclosed nonpublic information confidential, and the relationship at least must imply such a duty.

Dirks v. SEC, 463 U.S. 646, 655 n.14 (1983).

45. See SEC v. Lerner, No. 9049, 1980 WL 1388, at $* 1$ (D.D.C. Apr. 2, 1980) (determining that attorney cannot purchase stock of client based on confidential information in his possession).

46. LANGEVOORT, supra note 43 , at $\$ 3.02$ [3]; WANG \& STEINBERG, supra note 42 , at $\S$ 
temporary insiders of the manufacturer. ${ }^{47}$ But the temporary insider doctrine would not apply to most forms of trading in stock substitutes. It would not apply, for example, to the paradigm case with which we began this Article: the Intel executive using material nonpublic information about Intel's quarterly earnings to profitably trade in a competitor's stock. And even when an employee of one firm is a temporary insider of another firm (and hence restricted from trading on its stock), substitute trading in yet other companies may still be profitable. For example, in the Dilbert cartoon displayed at the beginning of this Article, Dilbert and his fellow employees may be temporary insiders of the air traffic control corporation (because of the contractual relationship between Dilbert's firm and the air traffic control company), but Dilbert would not be a temporary insider of "Bluehound Bus Lines."

\section{B. The Misappropriation Doctrine}

\section{Generally.}

In recent years, the reach of Rule10b-5 has been expanded considerably by judicial acceptance of the so-called "misappropriation" doctrine. Under that doctrine, a fiduciary who breaches the confidence of a principal and profits from that breach through the sale or purchase of securities has violated Rule10b-5. The violation occurs whether or not the trader is a fiduciary of the company whose stock she has traded. The fraud is on the party whose confidence has been breached, rather than the person on the losing end of the securities trade. Thus, a lawyer hired by Intel who, through her representation of Intel, obtains information about Compaq and contravenes her client's intentions by secretly trading on that information has violated Rule 10b-5. She has breached a fiduciary duty to her client, deceived her client by not announcing her intention to trade, and profited from that deception through the securities markets. ${ }^{48}$ In contrast, under traditional doctrine, the lawyer would

47. These situations might also give rise to Section $10(\mathrm{~b})$ liability under a misappropriation theory. See discussion infra Part II.B.2.

48. If the attorney announces her intention to trade, she is apparently not guilty of violating Rule 10b-5-even if the announcement comes after she has gained access to information and the principal is powerless to prevent her from trading. The reason for this is that liability requires deception; and according to dicta in the one Supreme Court decision on point, a fiduciary who announces her intention to trade has not deceived her principal. United States v. O'Hagan, 521 U.S. 642, 643 (1997). If one accepts the premise of the misappropriation doctrine, this limitation on the doctrine-labeled by some scholars as"don't ask, just tell"--seems incorrect. See Richard W. Painter, Kimberly D. Krawiec, \& Cynthia A. Williams, Don't Ask, Just Tell: Insider Trading After United States v. O'Hagan, 84 VA. L. REV. 153 (1998). It seems more reasonable to find deception in using a position of trust to gain information. So defined, the deception would not be cured by disclosing an intention to trade on the information. In practice, fiduciaries who trade are unlikely to disclose their intentions to their principal, in large part because disclosure may bring other 
be a temporary insider, or fiduciary of Intel, and would be guilty of violating Rule $10 \mathrm{~b}-5$ only if she traded in Intel stock. The misappropriation doctrine is sometimes described as one of fraud-on-the-source. The victim for whom the trader is punished is the person whose confidence has been breached.49 Examples of situations in which courts have found $10 \mathrm{~b}-5$ violations under the misappropriation doctrine include a psychiatrist using information gleaned from a patient to trade Bank of America securities; ${ }^{50}$ a son using information gleaned from his father to trade call options in the Amax Corporation;51 a reporter using information that under contract belonged to his paper to trade on stocks appearing in future editions of the Heard on the Street column in the Wall Street Journal; 52 and a copyreader using information gained from a financial printer to trade on four future takeover (or "tender offer") targets. 53

\section{Employee trading.}

Trading rights defined by contract. Employees are obviously in a fiduciary relationship with their employers. Most of those convicted of $10(\mathrm{~b})$ violations under the misappropriation doctrine are convicted for using information belonging to their employers. ${ }^{54}$ Employees who work under an employment contract that forbids such trading and who nonetheless trade do so in clear

sanctions, including termination and civil or even criminal penalties under statutes other than Rule 10b-5. The discussion herein will assume that fiduciaries do not disclose trading intentions. This assumption is made to simplify exposition, and because we believe that disclosure is unlikely to serve as a serious limitation on liability.

49. The person on the losing side of the trade is a victim, too, at least in the economic sense that she loses on the trade. Without a securities transaction, there is no liability for misappropriation. But absent the breach of a fiduciary-like arrangement, the trader would not be punished for using information to her advantage and the other party's disadvantage. In the example above, the attorney hired by Intel could benefit from Intel information as to Compaq's prospects-so long as she had permission from Intel.

50. United States v. Willis, 778 F. Supp. 205 (S.D.N.Y. 1991).

51. Liability under misappropriation requires that the familial relationship leads to sharing of business confidences, and therefore becomes a fiduciary relationship. See United States v. Reed, 601 F. Supp 685 (S.D.N.Y. 1985); see also Selective Disclosure and Insider Trading, supra note 41, at 96-97 (applying theory of misappropriation in family settings); cf. United States v. Chestman, 947 F.2d 551 (2d Cir. 1991) (en banc), cert. denied 503 U.S. 1004 (1992) (holding that there is no fiduciary duty between a husband and wife for 10b-5 liability purposes).

52. United States v. Carpenter, 791 F.2d 1024 (2d Cir. 1986), aff'd 484 U.S. 19 (1987). Carpenter's conviction under the misappropriation doctrine was affirmed by a divided Court. The Court's decision in O'Hagan makes it clear that on similar facts the Court would uphold a conviction. O'Hagan, 521 U.S. at 654-55.

53. SEC v. Materia, 745 F.2d 197, 199 (2d Cir. 1984), cert. denied 471 U.S. 1053 (1985).

54. See, e.g., United States v. Libera, 989 F.2d 596 (2d Cir. 1993); Carpenter, 791 F.2d at 1028; Materia, 745 F.2d at 200. Misappropriation arising out of an employment relationship is discussed in LANGEVOORT, supra note 43 , at $\$ 6.04$, and WANG \& STEINBERG, supra note 42 , at $\$ 5.4 .2 .1$. 
violation of the misappropriation doctrine. It is just as clear that employees who are given express permission by their employer to use nonpublic information to trade in stock substitutes are not guilty of misappropriating information from their employer. Many employees, however, work under contracts that are silent on this issue. Can such employees trade?

Trading rights not defined by contract. Analytically, it might be useful to imagine two distinct default rules that might govern employee trading rights. Under what we refer to as a fiduciary-sourced default, an employee could not use material nonpublic information obtained through her employment to trade on stock substitutes unless she had the permission of her employer. Under what we refer to as a possible harm standard, an employee would be prohibited (absent permission) from only those trades that posed a real possibility of harm to her employer. The "possible/probable harm" standard resonates as a "hypothetical" or "majoritarian" default55 -in that it seems to be the type of rule that most parties would contract for if expressly called upon to do sowhile the "fiduciary-sourced" standard resonates more as an "information forcing" or "penalty" default which forces employees to expressly contract ex ante for the right to trade or ex post to seek permission with regard to particular trades. ${ }^{56}$ Of course, it may be that a majority of parties actually prefer this kind of information forcing-so that employers can more directly negotiate share(s) in the benefits of information that flows to agents from the fiduciary relationship. The case law in this area is ambiguous. ${ }^{57}$

The misappropriation doctrine has been successfully invoked by the government even in cases in which there were no contractual or express limitations on trading. The government has successfully brought prosecutions under the doctrine in familial settings, where the limitations on trading are necessarily implicit. In the employment context, virtually all of the cases over implicit limitations involve an employee purchasing stock of a "target" company. 58 The target company has been either a company the trader's employer was about to acquire, ${ }^{59}$ a company that a client of the trader's

55. See Ian Ayres \& Robert Gertner, Majoritarian vs. Minoritarian Defaults, 51 STAN. L. REV. 1591 (1999).

56. See Ian Ayres \& Robert Gertner, Filling Gaps in Incomplete Contracts: An Economic Theory of Default Rules, 99 YALE L.J. 87 (1989).

57. For a brief summary of the law, together with commentary, see ARNOLD S. JACOBS, LITIGATION AND PRACTICE UNDER RULE 10B-5 at $\$ 66.02$ [b] (2000) ("While the cases have not definitively explored this question yet, the policies underlying the Rule suggest that a person could not exploit his knowledge of these nonpublic facts [and trade in stock substitutes].") (footnotes omitted).

58. An exception to the "target" employment misappropriation cases is United States v. Bryan, 58 F.3d 933 (4th Cir. 1995) (reversing the securities fraud conviction of a state lottery employee who traded in a company awarded a lottery advertising contract).

59. See SEC v. Clark, 915 F.2d 439 (9th Cir. 1990). 
employer was about to acquire, ${ }^{60}$ or a company in which the trader's employer was about to make a substantial equity contribution. ${ }^{61}$

The target cases are of course consistent with a fiduciary-sourced default, which requires an employer's permission before using employment-related material nonpublic information for stock substitutes trading. The target cases are also consistent with a possible harm theory. An employee who purchases a target stock may be seen by the government or court to be acting against the interest of her employer. If the employer is the acquirer, the purchase may drive the stock price up, or tip off others of an impending acquisition. ${ }^{62}$ If the employee works for a law or accounting firm, and the stock is of a target of a client of that firm, the purchase may tarnish the employer's reputation with the client, either because it hurts the client directly through increased stock price of the target, or because it destroys the law or accounting firm's reputation for confidentiality. Indeed, the target cases can even be explained not in terms of misappropriation at all, but instead as straightforward applications of the temporary insider doctrine. A lawyer working for a law firm representing either the acquiring or target company is in at least indirect privity with the target company, and hence might be deemed a temporary insider who cannot trade the target stock.

There have been a number of prosecutions brought for stock substitutes in stocks of supplier companies, rather than in target stocks. ${ }^{63}$ In these cases, however, the employee was violating an explicit employer prohibition on the use of material nonpublic information.

SEC Rule 10b-2 sets forth its interpretation of the misappropriation doctrine. That Rule does not explicitly address the fiduciary-sourced default issue in the employment context, although language in that Rule seems somewhat supportive of the more limiting fiduciary-sourced standard. ${ }^{64}$

60. For examples of investments in companies that were about to be acquired by an employer's clients, see United States v. Newman, 664 F.2d 12, 17-18 (2d Cir. 1981) (finding misappropriation of investment bank's confidence); SEC v. Musella, 578 F. Supp. 425 (S.D.N.Y. 1984) (finding misappropriation of law firm's confidence for purposes of a preliminary injunction hearing).

61. See Ex-Intel Engineer, 2 Others Face Charges of Insider Trading, WaLl ST. J., Sept. 5, 2000, at B5 (reporting that Intel employee and friends purchased call options in Ancor Communications prior to announcement that Intel was going to collaborate with and purchase stock in Ancor).

62. In many (if not most) circumstances the purchase will be too small to affect stock price. It may also be argued that the purchase, if large enough to affect price, might help the employer by putting more stock into "friendly" hands.

63. See United States v. Bryan, 58 F.3d 933 (4th Cir. 1995); SEC v. Alireza Hooshiari, No. 1 99-CV-2043 (N.D. Ga. Aug. 9, 1999) (entering consent decree where BellSouth employee traded in stocks of companies up for supply contracts); SEC v. William C. DeGarmo, No. 92-2347 (D. Colo. Dec. 2, 1992) (entering consent decree where counsel for Lawrence Livermore National Laboratory traded in stock of computer company up for supply contract).

64. The Rule provides that misappropriation occurs "whenever the person 
In practice, in the absence of explicit agreement as to trading rights, a court or the SEC may well look to evidence of an implicit agreement. Both company and industry norms are relevant here. Similar trading carried out by other employees or similar trading carried out by the employee in question that was known to management and not objected to should largely insulate the trading from legal challenge. The contemporaneous reaction of the company after learning about a trade would likewise provide evidence as to the implicit understanding in that particular employment relationship. ${ }^{65}$

We provide some anecdotal information as to trading practices in stock substitutes and the corporate response to the misappropriation issue below. ${ }^{66}$ In general, and as noted therein, there is very little contracting on this issue either expressly permitting or expressly prohibiting employees from engaging in substitute trading. Explicit prohibitions are most common in the securities industry, where there is an awareness of the problem. Even there, however, most corporate counsel take a facts-and-circumstances approach to the application of the misappropriation doctrine to trading in stock substitutes: Employees are often required to report all trades, which can be audited for reputational or legal concerns.

In Silicon Valley, some firms take a conservative approach and provide explicit prohibitions on using corporate information to trade on substitute

communicating the material nonpublic information and the person to whom it is communicated have a history, pattern or practice of sharing confidences, such that the person communicating the material nonpublic information has a reasonable expectation that the other person would maintain its confidentiality." The Rule establishes a default assumption that such expectation of confidentiality exists between immediate family members but provides that assumption may be overcome by the facts and circumstances surrounding the trading. The release accompanying the issuance of the then-proposed rule states that "[c]ertain types of business relationships by themselves provide the duty of trust or confidence necessary in a misappropriation case. In O'Hagan, for example, the attorneyclient relationship established the duty of confidence. In other cases, the agency relationship inherent in an employer-employee relationship provides the duty ...." Proposed Rules Securities and Exchange Commission, Exchange Act Release Nos. 33-7787, 34-42259, IC24209, 64 Fed. Reg. 72590-01 (Dec. 28, 1999).

65. The source and degree of materiality of the information may also be relevant. Materiality has been defined, generally, as information that may be relevant to the reasonable investor. See Basic, Inc. v. Levinson, 485 U.S. 224, 224 (1988). Under traditional 10b-5 doctrine, information is either material or it is not; any materiality is sufficient for conviction (provided other elements of the offense are met). Controversy centers around whether information is or is not material. See LANGEVOORT, supra note 43, at $\S 5.02$; WANG \& STEINBERG, supra note 42 , at $\$ 4.2$. The misappropriation doctrine looks to the nature of the relationship and implicit norms; these norms may well be different depending on the degree of materiality. Trading on one type of information-or information which has some but not great relevance for stock price-may be common and within corporate norms; trading on another type of information with greater impact on stock price may fall outside those norms. The degree of materiality might also be a factor in the decision of a government official as to whether to bring a $10 \mathrm{~b}-5$ action based on a relatively novel application of the misappropriation doctrine.

66. See infra Part IV. 
stocks. Other firms limit only transactions in and relating to competitor stock. The reason given for this restriction is that mergers are common in the area, and companies are worried that innocent employee trading prior to a merger might get detected by the SEC, with the employee and/or company then having the burden to in effect prove that the trading was innocent. Most companies, however, have no express limitations. Most counsel would caution employees in the possession of material nonpublic information not to trade in substitute stocks on the fear that the SEC might in fact prosecute the matter. As one counsel for high technology companies put it, "You'd end up having the case dropped or winning your case, but would it be worth the profit to go through an SEC investigation?"

\section{Employer trading.}

The freedom of corporations themselves to engage in substitute trading is even more clearly established. While insider trading law restricts corporations from trading on their own shares on the basis of material nonpublic information, no current law prevents a company from using this same information and profitably trading on other companies' stock. Under O'Hagan, a corporation's use of its own information to trade on other stocks is not deceptive-you cannot deceive yourself-and hence would not run afoul of the misappropriation doctrine. A former chief economist of the SEC, Susan Woodward, was asked if it would be legal for Company A to trade in Company $B$ shares on the basis of information generated with Company A. She responded: "All [eight securities lawyers] said that 1) it is legal to trade rivals' stock; 2) even at its most imperious, the SEC has never suggested that this is illegal; and 3) they had never heard of such a case being brought, or even episodes of such trading questioned." 67 Thus, corporations have virtually no limit on substitute trading. 68

67. Hansen \& Lott, supra note 5 , at 273 n.16.

68. The only exception to this unrestricted ability of Corporation $A$ to trade on Corporation B's stock might arise by the operation of some contract between the two corporations. If an intercorporate contract implicitly or explicitly limits one corporation's ability to trade on the other, then insider trading liability for substitute trading might arise. For example, Corporation A might be deemed a temporary insider of Corporation B with regards to trading on particular types of information. Or alternatively, Corporation A may have implicitly promised not to trade on Corporation B's stocks when doing so would impose probable costs on B or its shareholders. Again, the previously noted Carlton and Fischel example is instructive. The corporation that sells a major customer's stock short before anticipatorily repudiating a supply contract faces a risk of insider trading liability. In the case of the aforementioned executive who sold short before causing her corporation to breach, the question was whether the executive breached an implicit promise to disclose to her own corporation all trades driven by information about potentially tainted decisions. With regard to the trades of the corporation itself, the crucial question is instead whether corporate trading would breach one corporation's implicit promise not to trade in ways that would impose a probable harm on the corporation or its shareholders. 


\section{Other Federal Limitations on Trading in Stock Substitutes}

\section{Mail and wire fraud.}

Section $10(\mathrm{~b})$ and Rule 10b-5 are supplemented by federal mail and wire fraud statutes. The mail and wire fraud statutes apply to "any scheme or artifice to defraud" that uses the mails or wires, respectively. There is no statutory guidance as to what constitutes a scheme to defraud in the context of stock trading. ${ }^{69}$ In practice, the interpretations of the mail and wire fraud statutes seem to follow the interpretation of Section 10(b). Many cases brought under 10 (b) also allege mail and wire fraud; a conviction on $10 \mathrm{~b}-5$ is usually accompanied by a conviction for mail and wire fraud. ${ }^{70}$ The rough equivalence between the provisions extends to cases litigated under the misappropriation doctrine. ${ }^{71}$ Courts generally decide the merits of the 10b-5 action; the mail and wire fraud counts are disposed of briefly, in the same fashion and with the same stated rationale as the $10 \mathrm{~b}-5$ counts. ${ }^{72}$ Mail and wire fraud therefore might apply to employee trading in stock substitutes under a misappropriation-like theory. Since the application of the statutes is derivative upon the misappropriation doctrine, it would be limited in the same way the misappropriation doctrine is limited. The statutes would therefore not apply to trading in stock substitutes carried out by a corporation, or to employees trading with their employer's permission.

\section{Rule $14 e-3$.}

Rule 14e-3 imposes a "disclose or abstain" rule on material nonpublic information concerning a tender offer in cases in which a trader knows or has

69. The mail fraud statute provides, in relevant part:

Whoever, having devised or intending to devise any scheme or artifice to defraud ... places in any post office or authorized depository for mail matter, any matter of thing whatever to be sent or delivered by the Postal Service... [or] private or commercial interstate carrier, or takes or receives therefrom ... any such matter or thing... shall be fined under this title or imprisoned not more than five years, or both.

18 U.S.C. $\$ 1341$ (2000). The wire fraud statute is similar. See 18 U.S.C. $\$ 1343$ (2000).

70. Courts have interpreted the seemingly distinct element of mail fraud-the use of the mails - to be satisfied whenever the trade in question triggers a mailing. This includes the mailing of stock certificates or broker confirmation slips. The distinctive element in wire fraud is disposed of in similarly summary fashion. See WANG \& STENBERG, supra note 42, at $\$ 11.31$.

71. See, e.g., Carpenter v. United States, 484 U.S. 19 (1987); United States v. Chestman, 947 F.2d 551 (2d Cir. 1991) (en banc), cert. denied, 503 U.S. 1004 (1992).

72. Thus, for example, the Second Circuit in Chestman held the defendant not guilty of misappropriation in a lengthy opinion, and then dismissed the mail and wire fraud counts, saying only, "The fortunes of Chestman's mail fraud convictions are tied closely to the securities fraud convictions." Chestman, 947 F.2d at 571. 
reason to know that the information comes directly or indirectly from the offeror or target, or employees, directors, or agents of the offeror or target. Unlike Rule $10 \mathrm{~b}-5$, the scope of $14 \mathrm{e}-3$ is not limited to trading by a fiduciary in violation of confidence of a principal (misappropriation doctrine) or trading by a fiduciary against a principal (traditional 10b-5 liability). Rule 14e-3 applies in circumstances in which a person in a nonfiduciary capacity to either the trading party or the information source hears about a tender offer from an offeror or target. Thus, the rule would prohibit a waiter who overhears a director of an offeror discussing a pending tender from trading on that information; it would also prohibit an employer or company from trading in that same stock-provided again that the trade had its source in material nonpublic information from a target or offeror, director, employee, or agent of the same.

But the expansive coverage of $14 \mathrm{e}-3$ does not eliminate the possibility of substitute trading. Indeed, it may give rise to an impetus to engage in new forms of substitute trading. For while $14 \mathrm{e}-3$ prohibits trading on the firms involved in takeovers, it does not prohibit using nonpublic information about the takeover to profit from trading on other firms in the industry, upstream or downstream rivals, or the manufacturers of complementary products. Rule 14e-3 provides in part:

If any person has taken a substantial step ... to commence... a tender offer ..., it shall constitute a ... deceptive ... act ... within the meaning of section 14(e)... for any other person who is in possession of material information relating to such tender offer which information he knows or has reason to know is nonpublic and which he knows or has reason to know has been acquired directly or indirectly from [the acquirer, target or offeror, or employees or directors of the issuer or target] to purchase or sell ... any of such securities. ${ }^{73}$

The key words, "any of such securities," seem to limit the rule's application to trading on the stock of the target or the acquiring firm. In particular contexts, it is easy to guess that the announcement of the MCI/WorldCom merger would increase the stock price of AT\&T (it did); or that the announcement of the BP/Amoco merger would increase the price of rival oil companies (it did). 74 Economic theory suggests that $14 \mathrm{e}-3$ would cause some of the demand for informed trading about merging companies to shift instead toward trading on nonmerging rival firms (or customers or suppliers affected by the merger). 0

\section{State Law Limitations}

Under certain circumstances, employees who trade in stock substitutes may face state law penalties. Consider, first, civil liability to an employer for

73. 17 C.F.R. $\$ 240.14 \mathrm{e}-3$ (a) (2001).

74. See Steve Liesman, Bigger Oil; BP to Acquire Amoco in Huge Deal Spurred by Low Energy Prices, Wall ST. J., Aug. 12, 1998, at A1. 
violating her duty of loyalty to her corporate employer. Under the so-called "corporate opportunity" doctrine, profits realized by an insider from the usurpation of a corporate opportunity must be returned to the corporation. In order for the doctrine to apply, however, it must generally be shown that the corporation itself would have, or at least might have, availed itself of the opportunity. ${ }^{75}$ The "line of business" limitation to the corporate opportunity duty means, however, that in most jurisdictions the doctrine would only apply in situations in which a company has a practice of trading in stock substitutes and an executive of that company without permission trades in the same substitutes, robbing the company of the profits it makes off the trades. But most companies do not have a practice of trading in stock substitutes. ${ }^{76}$ Executives of those companies could trade without facing liability under the corporate opportunity doctrine. The relatively rare cases in which the corporate opportunity doctrine does apply would largely overlap with cases in which the misappropriation doctrine applies. ${ }^{77}$

There is some limited support for liability to the corporation even in cases in which the corporation itself is not harmed and the corporation itself would not have made the trade. ${ }^{78}$ The leading case in which this form of liability for traditional insider trading was found, Diamond v. Oreamuno, was cited approvingly by the Supreme Court in Carpenter in upholding a 10b-5 conviction under the misappropriation doctrine:

It is well established, as a general proposition, that a person who acquires special knowledge or information by virtue of a confidential or fiduciary relationship with another is not free to exploit that knowledge or information for his own personal benefit but must account to his principal for any profits derived therefrom. 79

The "strict liability" aspect of Diamond has been accepted in some jurisdictions (including federal courts applying Delaware state law) and rejected in other jurisdictions. ${ }^{80}$ No cases litigated thus far have involved

75. See RoberT Charles Clark, CoRPorate LAW $\$ \$ 7.1-7.2$ (1986); James D. CoX, Thomas Lee Hazen \& F. Hodge O'NeaL, Corporations $\$ \S 11.7-11.9$ (1997).

76. See infra Part III, at p. 131.

77. The overlap would not be exact. Rule 10b-5 misappropriation liability would apply whenever nonrevealed insider trades violate an explicit or implicit understanding, whether or not the company ever trades. In that respect, $10 \mathrm{~b}-5$ liability encompasses a much greater set of circumstances. On the other hand, the corporate opportunity doctrine is broader in that it does not require that the information traded upon meet the legal definition of material or nonpublic, though as a practical matter, trading on information that does not meet those tests is unlikely to be actionable.

78. See WANG \& STEINBERG, supra note 42 , at $\$ 16.3 .2$.

79. Diamond v. Oreamunu, 23 N.Y.2d 494, 497 (1969), cited in Carpenter v. United States, 484 U.S. 19, 27-28 (1987).

80. See, e.g., Thomas v. Roblin Indus., Inc., 520 F.2d 1393 (3d Cir. 1975); Davidge v. White, 377 F. Supp. 1084 (S.D.N.Y. 1974) (Delaware law consistent with Diamond). Courts rejecting Diamond have insisted upon some showing of harm and have differed in their tests or judgment of what constitutes harm. Compare Freeman v. Decio, 584 F.2d 186 (7th Cir. 
trading in stock substitutes. Nonetheless, a state court that accepted the decision in Diamond and accepted the misappropriation doctrine as set forth in Carpenter might conceivably find that using nonpublic information to trade in stock substitutes constitutes a violation of fiduciary duty to the corporation, even absent a showing that the corporation itself ever traded, or was likely to trade, in stock substitutes. The Diamond approach to misappropriation is largely equivalent to the "fiduciary-sourced" default analyzed above. This expansive definition of what constitutes a corporate opportunity would give the corporation a property interest in all profitable trading opportunities growing out of proprietary (fiduciary-sourced) information.

What about liability to shareholders on the losing side of the trade under common law notions of fraud? In states that follow the so-called "special facts doctrine," insiders who trade in their company's stock may be liable for damages to shareholders who are at the losing end of those trades. Few successful cases have been brought under those doctrines since the adoption and expansion of $10 \mathrm{~b}-5 . \$ 1$ More to the point, the doctrines would not apply to trading in stock substitutes, for the same reason that traditional 10(b) liability would not apply: The insider has no fiduciary relationship with the shareholder on the losing end of the trade.

Neither the corporate opportunity doctrine nor the finding of liability under a theory similar to that set forth in Diamond would apply to employees who trade in stock substitutes with the permission of their employer, or to trading in stock substitutes undertaken by a corporation rather than its employees. Indeed, the whole thrust of the corporate opportunity doctrine is that in the first instance the corporation should have the option to profit from trading opportunities growing out of its agency relationships with it employees. It would be difficult to use such an analysis to support a conclusion that the corporation was prohibited from trading.

Insider trading is subject to attack under state blue sky laws in addition to common law standards of fraud and fiduciary duty. The majority of states have adopted a version of the Uniform Securities Act, which in Section 101 contains a provision modeled after $10 \mathrm{~b}-5.82$ Some states have eliminated a private cause

1978), with In re ORFA Sec. Litig., 654 F. Supp. 1449 (D.N.J. 1987). ORFA suggested that the harm might simply be that of lost goodwill. See generally LANGEVOORT, supra note 43, at $\$ 10.03[1]$.

81. Liability under these doctrines is limited, among other factors, by the exclusion of market (as opposed to face-to-face) trades, and the uncertain application of the doctrines to sales by insiders to persons who are not shareholders until after the sale. See WaNG \& STEINBERG, supra note 42 , at $\$ 16.2 .3$.

82. Section 101 of the Uniform Securities Act provides:

It is unlawful for any person, in connection with the offer, sale or purchase of any security ... (1) to employ any device, scheme, or artifice to defraud..., or (3) to engage in any act, practice, or course of business which operates or would operate as a fraud or deceit upon any person.

UNIF. SEC. ACT $\$ 101$ (amended 1958), 7 U.L.A. 110 (2000). 
of action for insider trading violations, and state enforcement is uneven. Not surprisingly, interpretations under Section 101 (as adopted by the states) tend to follow interpretations of $10 b-5.83$

\section{CURRENT CoRporate Practice}

This section looks briefly at two questions: "What do we know about how corporations regulate employee substitute trading?" and "How much do employees or the corporations themselves engage in such trading?" The truth is that we know very little.

On the contracting side, some firms have explicit policies restricting their executives from trading in other companies' stock. For example, United Technologies Corp. and Prudential Insurance Co. of America prohibit their employees from investing "in customers, suppliers or other business partners." 84 But such trading restrictions are often driven by conflict of interest concerns. Employers fear that employees may divert business toward firms in which they hold stock. This conflict of interest concern seems to be particularly true with regard to suppliers, and some trading restrictions accordingly are limited to employees' trading on potential or actual suppliers. $\$ 5$ The thought here seems to be that employees do not have any ability to favor consumers-so there is no conflict of interest in holding a customer's stock. ${ }^{86}$

Firms in the financial industry are perhaps understandably most cognizant of the problems of informationally based trading in related firms and aggressively regulate such trading by their employees. Employees of a brokerage firm are often prohibited from trading on related firms of its clientele. 87 Such restrictions are particularly easy to enforce as trading firms often require their employees not just to report but to place all their security trades through a particular desk.

The question of whether and when employers should allow employees to trade on related firms' stock is much more actively debated in the technology

83. See WANG \& STEINBERG, supra note 42 , at $\$ 16.4 .2$.

84. Glenn R. Simpson \& Scott Thurm, Web of Interests: At Cisco, Executives Accumulate Stakes in Clients, Suppliers, WALL ST. J., Oct. 3, 2000, at A1.

85. For example, Intel and Motorola do not allow senior managers to invest in companies that conceivably sell to Intel or Motorola. Id. Note that such a rule would not stop an Intel manager in our ongoing example from exploiting information about increased chip demand to profit from trading in, say, Compaq stock.

86. However, an employee might favor a customer by negotiating a lower price or by favoring the customer when the product is in short supply. And holding long positions in competitors' firms might easily create conflicts of interest for employees but at least in some firms go unregulated. Some firms (such as Hewlett Packard) go further and bar employees "from holding financial interests in any supplier, customer, reseller or competitor." Id.

87. Difficult issues arise as to what constitutes a client. For example, we spoke with brokerage firms that have struggled with whether reading an unsolicited prospectus restricts an employee's ability to trade on other stocks in the industry. 
sector-the so-called new economy. A few companies take a conservative position and ban all trading on material nonpublic information-including trading in stock substitutes. Other companies ban trading in competitors' stock. Some tech companies-flipping the foregoing conflict of interest concernactively encourage their employees to hold stock (and even board positions) in their suppliers so as to influence the supplier's future design choices. ${ }^{88}$ Others allow such trading but require that it be disclosed to and approved by management. ${ }^{89}$ The Manne-like notion that the income from substitute trading provides a substitute for traditional compensation resonates deeply in Silicon Valley. Allowing employees to trade on related firms is viewed "as a kind of disguised compensation which ultimately is in the best interest of shareholders." 90

In sum, we see some divergence in contracting practice. Some firms actively prohibit substitute trading-particularly in suppliers and less often in customers and rivals. ${ }^{91}$ Some firms allow it (or allow it if disclosed to and approved by management). But it is our impression that most employment contracts (outside of the financial and high-tech sectors) are silent as to these issues.

We know even less about actual substitute trading practices. To begin with, it is useful to distinguish information-driven trades from incentive-driven trades. The goal behind some trading on related firms is to profit by hedging risk or by altering decisionmakers' incentives instead of to profit by cashing in on nonpublic information. For example, there is some evidence that both employees and firms trade on related firms to hedge risk of their otherwise uncovered positions in a particular stock. Employees, for example, who are forced to hold substantial stock options in their firm may try to hedge some of their industry-specific risk by selling calls in their rivals' stock. ${ }^{92} \mathrm{~A}$ firm preparing for a takeover contest may similarly attempt to hedge industry risk by selling short shares in a competitor at the same time it purchases an initial stake

88. Simpson \& Thurm, supra note 84 ("Qwest ... encourages its executives to serve on suppliers' boards in the hope of influencing the design of telecom equipment.").

89. For example, at Cisco, employees "may not invest in companies that are Cisco customers, partners or suppliers with whom the employee acts for Cisco without disclosure to and written permission from the Cisco vice president for their organization." Id.

90. Id. (quoting John Boatright, head of an academic group called the Society for Business Ethics).

91. These contractual restrictions stand in contrast to Carleton \& Fischel, supra note 5, at $\$ 58$ (claiming that before the federal ban firms rarely contracted to prohibit traditional insider trading).

92. See David M. Schizer, Executives and Hedging: The Fragile Legal Foundation of Incentive Compatibility, 100 COLUM. L. REV. 440 (2000). Surprisingly few corporate contracts prohibit such hedging strategies. Stewart J. Schwab \& Randall S. Thomas, What Do CEOs Bargain For? An Empirical Study of Key Legal Components of CEO Contracts (Oct. 31, 2000) (unpublished manuscript, on file with authors) (reporting that 62 of 93 sampled contracts with CEOs discussed stock option compensation, eight restricted sale of options, with three of these restricting pledging and zero restricting hedging transactions). 
of a potential acquiree. There is some evidence of special trading desks that exist to accomplish these hedging functions.

There is also evidence of cross-holding a rival's stock in order to facilitate collusion. David Gilo has detailed several instances in which a company has passively invested in the stock of its competitor:

For example, recently, Microsoft passively invested in $\$ 150$ million worth of nonvoting stock of Apple, its historic rival in the operating-systems market.... TCI, the nation's largest cable operator became a passive investor with a $9 \%$ stake in Time Warner, the nation's second largest cable operator. Gillette, the international and U.S. leader in the wet-shaving razor-blade market, acquired as a passive investment $22.9 \%$ of the nonvoting stock and approximately $13.6 \%$ of the debt of Wilkinson Sword, one of its largest competitors. There are also several cases in which a firm's controlling shareholder invests in the firm's competitor. A striking example existed, for several years, in the car-rental industry: National Car Rental's controller, GM, acquired a $25 \%$ stake of Avis, National's competitor. In the very same industry, it was reported that Hertz's controller, Ford, had acquired $\$ 324$ million worth of Budget's nonvoting stock..$^{93}$

Bizarrely, under the Clayton Act, ${ }^{94}$ such investments are exempt from antitrust scrutiny because they are made "solely for investment"-even though their predictable consequence is less competitive pricing.95 Instead of permitting such anticompetitive cross-holding, one of us has suggested that government should at times require procompetitive, merging firms that force cross-holding to sell their rivals' stock short. ${ }^{96}$ But neither the hedging nor the cross-holding transactions are driven by a desire to profit on nonpublic information.

What little we do know about information-driven trading on related firms (as a substitute for insider trading) suggests that some employee trading occurs but that firms such as Intel do not seem to exploit nonpublic information to trade on stock substitutes. We can be fairly confident about the absence of corporate-level trading because corporations' financial statements would disclose their success in such transactions as an unusual profit item, ${ }^{97}$ and such disclosures are nowhere to be found. When we have informally asked executives why they don't engage in such trading, they variously tell us that it

93. David Gilo, The Anticompetitive Effect of Passive Investment 4-5 (John M. Olin Discussion Paper No. 189, Harvard Law School, 1996) (footnotes omitted).

94. 15 U.S.C. $\$ 12$ (1914).

95. Gilo, supra note 93 , at 7 .

96. See Ian Ayres \& Stephen F. Ross, "Pro-competitive Executive Compensation" as a Condition for Approval of Mergers that Simultaneously Exploit Consumers and Enhance Efficiency, 19 CANADIAN COMPETITION REC. 18 (1998).

97. Revenues from sources other than primary business activities, if "unusual" and "infrequent," as defined by APB Opinion 30: Reporting Results of Operations, are reported as "extraordinary item[s]" on a firm's balance sheet. See RoBERT S. KAY \& D. GERALD SEARFOSS, HANDBOOK OF ACCOUNTING AND AudITING 13-31 (1989). 
would not be consistent with their firm's corporate culture 98 or that it's simply not worth it given the financial and litigation risks involved. Our previous simulation of the potential profitability from such trading partially supports these accounts.

Employees who can more effectively exploit options markets, however, can reap a larger return on less capital. Anecdotes of such employee trading are known, but the exact extent of the phenomenon is not. The Wall Street Journal reports that investments by an employee in a customer or supplier "are common among high-tech businesses"99_-but even here it is hard to know how much of this is based on nonpublic information. We know that Jay Gould traded on the private information that his telegraph company was about to enter a particular geographic market, ${ }^{100}$ and there are inklings that insiders at Kodak traded on Polaroid because they knew about their company's forthcoming entry into the instant-photo market. 101 And a trading strategy that is trumpeted in a "Dilbert" cartoon strip must certainly have occurred to some employees. But our ignorance about the size of this "problem" at both the corporate and insider levels is itself a primary justification for the disclosure rules we propose. ${ }^{102}$

\section{DESIRABILITY OF TRADING IN STOCK SUBSTITUTES}

\section{A. Current Thinking on the Desirability of Insider Trading}

Is trading in stock substitutes socially desirable? Consistent with one branch of scholarship in this area, we focus on the efficiency (as opposed to fairness) issues raised by such trading. ${ }^{103}$ We focus first on the desirability of restrictions on "ordinary" insider trading, that is, trading by an employee in the stock of her employer, or trading by the employer in its own stock.

Opponents of the present restrictions on insider trading make three related arguments. ${ }^{104}$ First, insider trading by an employee in the stock of her

98. See also Rotemberg and Saloner, supra note 36.

99. Simpson and Thurm, supra note 84 .

100. See supra text accompanying note 14 .

101. See supra text accompanying note 11.

102. See infra Part V.

103. For a nonefficiency based exploration of the subject, see Alan Strudler \& Eric W. Orts, Moral Principle in the Law of Insider Trading, 7S TEX. L. REV. 375 (1999).

104. There is a substantial body of literature on this subject. The literature is generally dated from the publication of Henry G. Manne's article, In Defense of Insider Trading, Harv. Bus. Rev., Nov.-Dec. 1966, at 113. See also HeNRY G. MANNE, Insider Trading AND THE STOCK MARKET (1966); Henry G. Manne, Insider Trading and the Law Professors, 23 VAND. L. REV. 547 (1970) (responding to critics). A summary and extensive bibliography of the literature can be found in STEPHEN BAINBRIDGE, INSIDER TRADING, ENCYCLOPEDIA OF LAW AND ECONOMICS (1999). See also Jie Hu \& Thomas H. Noe, Insider Trading and Managerial Incentives, 25 J. BANKING \& FIN. 681 (2001) (suggesting under 
employer is most appropriately viewed as a form of compensation to the employer-trader. All else equal, trading profits reaped by insiders and lost to other shareholders could be recouped (on an ex ante basis) through adjustments to the wage contract. Once insider trading is seen as part of the wage contract, problems of fairness disappear, at least on an ex ante basis. Shareholders run the risk of being on the wrong end of a trade with an insider who possesses material nonpublic information, but pay less in the form of explicit compensation. Shareholders will also be among the classes that benefit from any efficiencies produced by insider trading, which are described below.

Second, insider trading would produce more accurate stock prices. Insiders who possess positive material nonpublic information would purchase stock, thereby driving the price up to reflect underlying value; insiders would sell on negative information, thereby driving the price down to underlying value. More accurate stock pricing would reduce risk to those who purchase stock or depend on stock value to make lending or employment decisions. ${ }^{105}$ This last category would include employees who accept stock options as a part of their wage contract. More accurate stock pricing would also lead to better allocation of resources. Absent insider trading, a firm whose value is in part attributable to positive material nonpublic information will find it more expensive to access financial or human capital markets than another equally valuable firm whose value is fully impounded in stock price. Insider trading equalizes stock price and so removes that source of distortion.

Third, present insider trading restrictions rely on distinctions that are difficult to draw, difficult to enforce, and normatively unsatisfying. As noted in Part $I$, a trade is not illegal unless information used or possessed is "material"; defining materiality and applying that definition in a given case is a difficult task. The rules prohibit trades based on discrete pieces of information; allowed are equally advantageous trades based on the ability to synthesize and make use of publicly available information. Yet this ability is often learned on the job and is itself perhaps a function of less-identifiable nonpublic pieces of information. Other problematic areas include the determination of damages, standing to sue, treatment of instruments with debt-like characteristics, application of the misappropriation doctrine, application of the rules to tippees, and the question of whether an insider who possesses information and trades but who does not use the information to guide her trading behavior (i.e., who would have traded anyway) has violated the rules. ${ }^{106}$ Some commentators have speculated that these costs alone outweigh any benefits of the restrictions. 107

limited circumstances that allowing managers to trade may better impound information about hidden managerial action); Jonathan R. Macey, Securities Trading: A Contractual Perspective, 50 CASE W. RES. L. REV. 269 (1999).

105. See Carlton \& Fischel, supra note 5 , at $866,867$.

106. See WANG AND STEINBERG, supra note $42, \S 5.2 .3$.

107. See Carlton \& Fischel, supra note 5, at 873. An excellent discussion of the 
The efficiency gains from insider trading, however, may be offset (and perhaps more than offset) by efficiency costs. While insider trading reduces risk created by inaccurate stock pricing, it increases risk to the insider who receives trading rights in place of other (presumably more secure) forms of compensation. 108 Insider trading may distort the flow of information to investors as insiders time the flow of information to maximize trading gains. 109 Insider trading may also discourage the flow of information within a firm. Information sharing increases the number of insiders who trade on nonpublic information; increased trading may affect share price and thus reduce profits to each insider. ${ }^{110}$ Insider trading may affect resource allocation within a firm, as managers are encouraged to select those projects that maximize potential trading gains. ${ }^{111}$ Risky projects offer more potential trading profits than safe projects-provided the insider is able to trade before knowledge of the project's outcome reaches the public. Insider trading may distract executives from other firm business. Finally, for large companies, insider trading may be significant enough to distort managerial behavior, but not significant enough to affect the stock pricel12_a possibility which is described in more detail below.

Debate over insider trading has proceeded in a point/counterpoint fashion: Arguments on one side produce counterarguments on the other side. For example, opponents of present law have argued that increased risk taking due to insider trading will offset overly risk-averse behavior of executives and therefore will increase, rather than reduce, welfare. ${ }^{113}$ Opponents of present law do not argue that insider trading will always be more efficient, only that it will often be more efficient, and companies ought to be able to elect whether or not they wish to allow such trading. ${ }^{14}$

problems with both Rule $10 \mathrm{~b}-5$ and insider trading can be found in Jesse M. Fried, Reducing the Profitability of Corporate Insider Trading Through Pretrading Disclosure, 71 S. CAL. L. REV. 303 (1998). Fried advocates supplementing Rule 10b-5 restrictions with a regime of pretrading disclosure.

108. See Frank H. Easterbrook, Insider Trading, Secret Agents, Evidentiary Privileges, and the Production of Information, 1981 SUP. CT. REV 309, 332 (1981); Kenneth E. Scott, Insider Trading: Rule 10b-5, Disclosure and Corporate Privacy, 9 J. LEG. STUD. 801, 808 (19S0).

109. See Easterbrook, supra note 108, at 333; Paul E. Fischer, Optimal Contracting and Insider Trading Restrictions, 47 J. FIN. 673 (1992).

110. See generally Robert J. Haft, The Effect of Insider Trading Rules on the Internal Efficiency of the Large Corporation, $80 \mathrm{MicH}$. L. REv. 1051 (1982).

111. Saul Levmore, Securities and Secrets: Insider Trading and the Law of Contracts, 68 VA. L. REV. 117, 149 (1982).

112. See Ronald J. Gilson \& Reinier H. Kraakman, The Mechanisms of Market Efficiency, 70 VA. L. REV. 549 (1984).

113. See Carlton \& Fischel, supra note 5, at 876.

114. See MANNE, supra note 104, at 421; Carlton \& Fischel, supra note 5, at 877. 


\section{B. Hypothetical Auctions and the Quasi-Dominance of Firm vs. Managerial Trading}

We extend the analysis of traditional insider trading by pointing out that incorporating trading rights into a wage contract ties together unrelated activities: trading stock and managing a company. The result is apt to be an inefficient means of obtaining either objective. For this purpose, it will be useful, first, to consider a simple auction of insider trading rights. The purchaser would have full access to nonpublic corporate information. The value of such rights would depend on the size of the company, characteristics of stock movement, and the ability to translate information into trading profits. That value is certainly large; for some companies, the value would be enormous. For a Fortune 500 company, the right to trade on nonpublic information might be worth hundreds of millions or even billions of dollars per year. ${ }^{115}$

This auction standard is consonant with Carlton and Fischel's statement of the basic inquiry: "[T]he dispute concerning insider trading is really a dispute about which party more highly values a property right [in information] ...."116 They-like us-believe: "Whether insider trading is beneficial depends on whether the property right in information is more valuable to the firm's managers or to the firm's investors." 117 However, unlike these authors who conclude that a firm's managers are likely to be the highest valuers of the information, we believe there are reasons why managers would be unlikely to be the highest bidders in the auction.

A rule that allows managerial insider trading effectively ties such an auction to the hiring of each high-level executive. One can imagine a company considering two executives for a single slot, with each executive coming armed with a bid backed by an investment bank. The value of trading rights "purchased" might be greater than the value of executive services "sold"; the company would receive executive services plus a substantial sum of money; the executive would receive a percentage of trading profits. The process might produce bids that differ by hundreds of millions of dollars. In some cases, the company might be better off by hiring a less-favored executive with a high bid over a more-favored executive with a low bid. Yet the company would be better off still by decoupling the hiring decision and sale of bidding rights-

115. See supra Part I.B (estimating the potential profits from trading on a single piece of nonpublic information on stock substitutes). Determining the value of trading rights would be extremely difficult and would require the expenditure of considerable resources; one would expect the auction to be won by an investment bank or similar institution. Investment banks would reduce their bid below expected value to reflect risk; yet managers and shareholders may see the sale as creating, rather than reducing, risk.

116. Carlton \& Fischel, supra note 5, at 865.

117. Id. at $\$ 63$. 
thereby hiring the best executive and selling trading rights to the highest bidder. Selling bidding rights in return for service is a barter arrangement. In a small company, perhaps this kind of arrangement would be sensible. Executives would have some idea of the relationship between nonpublic information and stock movement, and trading profits would not be great enough to support the placement of professional stock traders within the company. This would not be true for a company of any substantial size.

One might reject the auction process and instead imagine a company that first selects whom it believes to be the best executive and then asks her to bid on unlimited trading rights. Both the company and the executive would then have to value the rights. Since there is no reason to believe that the best executive will give the best price for the trading rights, the company is again faced with the downside of tying the purchase of services to the sale of trading rights.

Most companies, of course, would have a number of executives privy to some forms of nonpublic information. The executives might compete away some of the trading profits and thus lessen the amount at stake in the sale of trading rights. On the other hand, the executives may vary in their access to nonpublic information, thereby requiring a separate auction or analysis for each executive. And the possibility of explicit or implicit collusion between executives would make valuation even more difficult.

It might be objected that it is fanciful to think that a company would auction off positions or allow an executive to engage in unlimited trading on nonpublic information. Instead, a company might place "sensible" limits on such trading. The executive might be allowed to place a limited dollar amount of trades per year or realize a limited amount of trading profits. The limit would be such that it would be readily attainable by the executive. A corporate president might be allowed a few million dollars of such trades or a few million dollars in trading profits. This approach would eliminate the requirement that the executive partner work with a professional trader. If the limit were low enough, the value of the rights would be the same to the entire pool of potential managers. The company could then hire the best manager-whether the manager were an able or well-funded trader would be irrelevant. The difficulty with this approach, however, is that such limited trading would not affect stock price, which is the primary objective of any regime that would permit insider trading.

What can we learn from our auction metaphor? First, to paraphrase the "Annie Get Your Gun" lyric, anything an insider can do, the firm can do better. Prior analysts-like Carlton and Fischel-have tended to compare the benefits of insider trading by managers to a world in which no one (or only outsiders eventually) trades on nonpublic information. ${ }^{118}$ But most of the arguments 
showing that managerial insider trading would be more efficient than an absolute ban prove too much because these arguments also tend to suggest that trading by the firm itself would tend to be even more efficient. In other words, insider trading by the firm itself tends to dominate insider trading by managers.

Insider trading by the firm itself does not give rise to the perverse "moral hazard" incentive to choose investments that are too risky, or to intentionally drive down the value of the firm. In addition, most insiders only have the wherewithal to buy a limited amount of insider trading rights, which means that there will only be a muted impact on the stock price. Furthermore, by trading on its own account, the firm is more likely to garner larger monopoly-like rents on its nonpublic information. In contrast, giving multiple insiders the right to trade on this information dissipates the value of the trading right. Bidding for the right to be one of dozens of people who can trade on nonpublic information is likely to be less valuable than bidding for the sole right to trade on the information. Insider trading by the firm itself thus will tend to produce even more accurate stock prices without exposing the firm to the potential costs of insider trading by managers.

More generally, we see there are a variety of different paths along which material nonpublic information may impact stock price, including: (1) firm trading; (2) insider trading; (3) broad-based disclosure to the market; (4) analyst trading; and (5) trading by suppliers, customers, rivals, and complementors (and their employees). At times, firms will prefer broad-based dissemination of information to preempt the ability of insiders or outsiders to trade on the information. ${ }^{119}$ At other times, firms may prefer silence either to slow the speed of dissemination or with the purpose of increasing analysts' returns for following the firm. 120 Our analysis here merely suggests that firm trading is likely to dominate insider trading. The dominance result is important because, even though managerial insider trading may be efficient relative to a

announce publicly because an announcement would destroy the value of the information, would be too expensive, not believable, or-owing to the uncertainty of the informationwould subject the firm to massive damage liability if it turned out ex post to be incorrect.

Id. at 868 . But this analysis ignores that the firm could also convey information by trading on the firm's own account. Such trading by the firm itself would give the firm much more control over how much information it conveyed to the market and when the information was conveyed.

119. Ian Ayres, Back to Basics: Regulating How Corporations Speak to the Market, 77 VA. L. REV. 945, 995 (1991).

120. Zohar Goshen \& Gideon Parchomovsky, On Insider Trading, Markets, and "Negative" Property Rights in Information 5-8, 12-14 (unpublished manuscript, on file with the authors). These authors make a strong argument that analyst trading-and at times even selective analyst disclosure-will be preferred to managerial trading. But as with other analyses of the problem, their focus is too dichotomous. A default prohibition against managerial trading may also be valuable in pushing firms toward broad dissemination of nonpublic information. The lower the turnover of the stock, the more the company will want to use broad dissemination to prevent analysts or insiders from unnecessarily profiting from information-driven trading. 
complete prohibition on informed trading, it can still be presumptively inefficient to the extent the firm can accomplish the same benefits without creating as great a risk of perverse managerial incentives. ${ }^{121}$

We readily acknowledge that this dominance tendency will not always hold true. Allocating an insider trading right to managers might nevertheless be efficient if, for example, managers brought independent knowledge to the jobs that made them more efficient evaluators of the firm's nonpublic information than the corporation itself. Michael Dell, for example, might have independent knowledge of the computer industry that would make him a more efficient trader on the information generated by Dell Computers than could be generated if he merely advised the Dell board on what trades he believed were profitable. ${ }^{122}$ Additionally, it may be efficient to hire managers who have commitments to multiple firms so that their trading will be informed by overarching data about a given sector. Carlton and Fischel have also argued that giving managers trading rights gives managers better incentives to identify valuable new investment opportunities: "If a manager observes a possible valuable investment for the firm-such as a potential value-increasing merger or a possible new technology-he will be more inclined to pursue this opportunity if he is rewarded upon success. Insider trading is one such reward."123

But we are skeptical of this argument. Giving the manager simple stock options or a bonus contingent on the firm's stock price seems to us a more tailored approach to giving employees appropriate incentives. ${ }^{124}$ Repealing the insider-trading prohibition and replacing it with a laissez-faire default would (absent an agreement to the contrary) give employees unlimited insider trading rights that might shower employees with profits incommensurate with those necessary to harness their efforts. ${ }^{125}$ So while we readily admit that firm

121. A similar argument can be made with regard to the defensive tactics of greenmail and lockup agreements. While Jon Macey and Fred McChesney showed that it might be efficient for a firm to pay a potential acquirer greenmail in order to induce other bidders to bid, there is still a strong argument that greenmail is inefficient because its auction-creating benefits can be maintained with lockup or standstill agreements that do not raise the risks of managerial entrenchment. See Ian Ayres, Analyzing Stock Lock-Ups: Do Target Treasury Sales Foreclose or Facilitate Takeover Auctions?, 90 CoLUM. L. REV. 682, 710-12 (1990).

122. See, e.g., Julie Johnsson, Dell, Insider Cut Back on Their Lante Stakes, CRAIN's CHI. Bus., Sept. 25, 2000, at 6; Talking Stocks (CNN television broadcast, Sept. 6, 2000).

123. Carlton \& Fischel, supra note 5 , at 871.

124. But see Thomas $\mathrm{H}$. Noe, Insider Trading and the Problem of Corporate Agency, 13 J.L. ECON. \& ORG. 287 (1997).

125. It is a frequent mistake of legal scholars to confuse arguments concerning the mandatory nature of law with arguments about what the optimal default should be. The opponents of insider trading prohibitions-including Manne, Carlton and Fischel-basically argue against the mandatory nature of the prohibition. But even if these arguments are accepted, one would need a separate set of arguments to determine whether default prohibition is more or less efficient than the default laissez-faire regime for which they argue. See Ian Ayres, Empire or Residue: Competing Visions of the Contractual Canon, 26 
trading will not dominate managerial trading in all contexts, we doubt that firms contracting to cede trading rights to their managers would often cede unlimited rights. Rather, we imagine that firms would more likely contract to (1) share in any managerial profits; (2) restrict the ability of managers to engage in informationally-driven short sales; and, most importantly, (3) require managers to disclose their trading to the firm after the fact. Ex post disclosure would help the firm assure that the prospect of trading profits had not distorted managers' decisionmaking and more accurately price the true value of such trading rights.

A substantive theory of when and what trading rights would be ceded is important because such agreements would constitute classic examples of selfdealing that should be subjected to both the substantive and procedural requirements of the duty of loyalty. ${ }^{126}$ Contracts permitting insider trading at a minimum should be approved by a majority of disinterested directors and should probably be subjected to substantive fairness review. The specter of managerial self-dealing undermines our confidence that the corporation's decision to allow managerial trading truly internalizes all the costs and benefits. Just as in the takeover context, where the fear of managerial self-interest might drive the decision to fend off a tender offer, heightened scrutiny is appropriate.127 Indeed, the presumptive dominance of firm trading, when combined with agency cost concerns, might even counsel for a per se (mandatory) prohibition against such trading. 128 But we would not go so far.

FLA. ST. U. L. REV. 897 (1999) (arguing that Dworkin and Epstein make similarly incomplete arguments regarding, respectively, libel and Title VII liability).

126. See, e.g., Lewis v. S. L. \& E., Inc., 629 F.2d 764, 769 (2d Cir. 1980) (holding that directors engaging in self-interested transactions must bear the burden of demonstrating that the transaction was "fair ... and reasonable to the corporation" and that they "may not escape review of the merits of the transaction"); Bayer v. Beran, 49 N.Y.S.2d 2, 6-7 (Sup. Ct. 1944) (holding that "transactions as may tend to produce a conflict between self-interest and fiduciary obligation, are, when challenged, examined with the most scrupulous care" and that courts would require not only "good faith," but also "inherent fairness").

127. See, e.g., Hilton Hotels Corp. v. ITT Corp., 978 F. Supp. 1342, 1346 (D. Nev. 1997) (holding that "[a] board's unilateral decision to adopt a defensive measure touching upon issues of control that purposefully disenfranchises its shareholders is strongly suspect" and cannot be upheld without "compelling justification" (citations omitted)); Unitrin, Inc. v. Am. Gen. Corp., 651 A.2d 1361, 1373 (Del. 1995) (holding that a court must apply enhanced scrutiny to directors in the takeover context before the directors can receive the protections of the business judgment rule); Paramount Communications Inc. v. QVC Network Inc., 637 A.2d 34, 42 (Del. 1994) (holding that "a court subjects directors' conduct to enhanced scrutiny to ensure that it is reasonable" when the corporation is about to break up or when there is a potential change or sale of corporate control); Revlon, Inc. v. MacAndrews \& Forbes Holdings, Inc., 506 A.2d 173, 185 (Del. 1985) (holding that the business judgment rule does not initially apply in the takeover context); Unocal Corp. v. Mesa Petroleum Co., 493 A.2d 946 (Del. 1985) (holding that defensive measures taken by a board must be reasonable in relation to the perceived threat to the corporation).

128. The analogy here might be to the traditional mandatory rule against managers' taking loans from corporations. Some jurisdictions have statutes in force establishing liability for proscribed corporate loans to directors and officers. See, e.g., Resolution Trust 
We would join the critics of present law in concluding that the mandatory prohibition against managerial insider trading is wrong. Limited trading rights for executives might on relatively rare occasions be sensible. A default prohibition with strict procedural and substantive fairness scrutiny of express attempts to opt out should be sufficient to ensure that managerial self-dealing does not lead to uncompensated transfers of the firm's trading rights. Our analysis suggests, however, that the costs of the present mandatory prohibition on employee trading are-judged on a system-wide basis-rather small.

On the other hand, our quasi-dominance results suggest that the current mandatory rule against firm trading may give rise to larger inefficiencies. The inefficiencies of the tying arrangement and the incentive problems can be avoided by having the company, rather than its employees, trade directly in its own stock. Indeed, as long as the company sells its trading rights in an arm's length transaction-for example, to investment banks or other professional trading concerns-we would only subject the arrangement to the much less searching business judgment rule. Both the costs and benefits of the firm trading itself (or selling the rights to a third party) are internalized to the corporation, and the corporation ought to be allowed to opt out of a default prohibition. We again would favor a default prohibition against insider trading by the firm (or its non-managerial delegate), but we would allow a firm to opt out in its articles of incorporation. ${ }^{129}$

\section{Desirability of Trading in Stock Substitutes}

How does our analysis change if the focus is on trading in another company's stock? In general, trading in stock substitutes by employees is likely to produce the same sort of costs and benefits as described above. However, many of these costs and benefits are externalized to the shareholders of the firm traded. On the benefit side, informed trading is likely to move stock prices toward their fundamental levels and to reduce the salary income of managers. On the cost side, informed trading is likely to increase the bid-ask spread of the traded firm and might induce managers to make wasteful and

Corp. v. Greer, 911 P.2d 257, 261 (Okla. 1995). While there are good reasons why managers might loan money to their firms, it is more difficult to justify corporate loans to the management. In the rare case, a corporation's loans to its own management might be an efficient investment, but the history of such lending has been so rife with unjustified selfdealing that the mandatory prohibition might be easily justified on rule utilitarian grounds.

129. A default prohibition might be justified as a majoritarian rule. For while we have argued that firm trading dominates managerial trading, we are agnostic as to whether firms would prefer broad dissemination or analyst trading as superior means to price nonpublic information. However, even if a majority of firms would ultimately opt for the ability to trade on their own stock, a default prohibition (especially in the transition) would provide potential shareholders with valuable information about whether they run the risk of facing a trading partner with systematically superior information when they buy or sell the company's stocks. See Ayres \& Gertner, supra note 55. 
inefficient decisions (which further their trading prospects). These social costs cannot be avoided through a rule that allows each firm to choose whether or not it wishes to be covered by the current insider trading rules. Nor can these costs be avoided by having the firm, rather than its employees, do the insider trading.

\section{The externalization of costs (and benefits).}

It might be useful to begin by focusing on the effect of trading in stock substitutes on managerial investment or resource allocation decisions. Quite clearly, there are some facets of enterprise operation that do not affect or provide information about other companies. ${ }^{130}$ However, many-and perhaps most-significant corporate initiatives will affect other firms. A risky investment in a new chip architecture, for example, may reduce the value of a competitor if successful and raise the value of the competitor if unsuccessful. This form of investment raises the full panoply of inefficient incentives described above. The expected value of trading profits may distort the decision to invest; the manager may withhold information from the public and other managers within the firm so as to profit from trading on the results; the trading will distract the executives from other firm issues; and so on. The same analysis applies to trading on information from past resource allocations. Information as to market share, profits, orders, future prices of raw materials, and the like offers opportunity to trade in stock substitutes, leaving the executive with incentives to control the flow of information and distracting the executive from other firm business.

The potential gains from trading in stock substitutes should produce the same effect on wage levels as gains from direct insider trading: Compensation ought to be (and presumably is) reduced by the expected value of the gains to the employees. The substitute trading would tend to move the stock price of the traded firm (and possibly the stock price of the non-traded firm) toward its fundamental value-but would also predictably increase the market maker's bid-ask spread. ${ }^{131}$ If employees are not the optimal traders, building this form of compensation into the employment contract will be inefficient.132 Again,

130. The settlement of a class action based on discrimination within a firm would fall into this category-provided, of course, the settlement did not affect or provide information about similar actions at other firms. The same could be said for adoption of a new trading strategy with temporary cash reserves. A firm may have some monopoly power over some portion of its market. Resource allocation decisions that affect profits within this imperfectly competitive space might similarly have no effect on-and provide no information aboutthe stock price of other companies.

131. The substitute trading might also impose costs on the firm whose stock was traded if it reduced the profitability for market analysts' following the firm. Reducing the trading profits of analysts could redound to the firm's detriment by reducing the liquidity and information services provided by analysts. See Goshen \& Parchomovsky, supra note 120.

132. We refer here to the costs of information-based trading. Executives may hold and trade other firms' stocks for other reasons, and these holdings may be positive or negative 
our quasi-dominance and self-dealing discussion is apposite. Substitute trading by the firm is likely to be more efficient than trading by its employees. There still is the possibility that employees will have independent knowledge or risk preferences that make them value the trading property more highly, but this consideration must be balanced against the risk that the managers will induce their corporation to permit substitute trading that is ultimately not in the corporation's self-interest.

All this is to say that substitute trading on the basis of nonpublic material information gives rise to the same basic categories of costs and benefits as traditional insider trading by managers on their own stock. However, with substitute trading, the costs and benefits accrue to different firms. The most salient difference between trading in stock substitutes and direct insider trading is that losses are not borne by the employer's shareholders; they are borne by the shareholders of the company whose stock is traded. A second important difference between the two types of trading is that, with substitute trading, the benefit of more accurate share pricing is realized directly not by the employee's company, but by the company whose stock is being traded. ${ }^{133}$

The externalization of costs and benefits makes it unlikely that a firm acting in its self-interest and without coordination with other firms would achieve an efficient rule with respect to employee insider trading. The firm's response would depend on the relationship between costs and benefits, which

for their employer. See supra Part III (discussing current corporate practice). For example, firms that compensate their executives with traditional stock (or stock option) incentives may want to regulate the executive's ability to hold substitute stocks. While the insider trading concern turns on the effects of the actual buying and selling, the incentive analysis turns on the effects of holding certain substitute securities. Firms with traditional stock incentive plans may need to prohibit executives from hedging away too many of their incentives. Ford executives might hedge the risk that they will lose market share to General Motors by buying General Motors stock; they might hedge their industry-specific risk by shorting stock of automotive suppliers. We have some anecdotal evidence that some brokerage houses have private trading desks to accomplish just such a function for executives. But economic theory suggests that firms at times will want to require a certain amount of stock substitute hedging. The standard principle-agent model suggests that firms will want to tie executive compensation to managerial effort as much as possible given managers' relative risk aversion. But the problem with many traditional stock incentives is that managers' compensation can be affected by exogenous shocks which drive the entire industry's stock prices up or down. If general movements in the industry's stock prices are exogenous to managerial effort, then the firm will want to create incentive structures that hedge away industry risk. Such a compensation plan might combine call options in an executive's own firm with put options on the rival firms. Hedging away industry risk loosens the risk aversion constraint and thereby allows firms to go further in tying a manager's compensation to her effort. For these purposes, this analysis suggests that firms will at times both require a certain amount of managerial holdings of stock substitutes to hedge away exogenous risk and simultaneously restrict managers from hedging away the residual incentives that the firm wants to maintain. As an empirical matter, few firms tend to make either of these requirements contractually explicit.

133. There is a possibility that the substitute trading will indirectly affect the stock price of the employee's own firm if, for example, the market infers a general sector shift. 
would vary from firm to firm and time to time. In general, however, it seems likely that the employees' gains from trading, unbalanced by the external losses suffered by shareholders of another company, would more than offset the internalized costs of such trading. If that is the case, a firm would rationally permit or even encourage trading in stock substitutes-even when such trading is socially inefficient. 134

To see how the externalization of costs and benefits can lead toward inefficient employer decisions, we provide here a highly stylized example. Assume that Intel employees could expect to earn 100x profit from trading in the stock of competitor Advanced Micro Devices ("AMD"). Since the trading is risky, the $100 x$ expected profits are valued by Intel employees at $90 x$. Trading distracts Intel employees, distorts the flow of information within Intel, and on occasion distorts investment decisions by Intel mangers. Intel values those costs at $5 x$. Trading produces a more accurate stock price of AMD; this is valued by $A M D$ at $2 x$ and generates an additional value of $1 x$ to those who base decisions on AMD stock price. Substitute trading produces social benefits of $93 x$ and social costs of $105 x .135$ If the true benefits and costs were internalized to Intel, it would not be allowed. In fact, Intel may reap benefits of $90 x$, through reduced compensation by the perceived value of the trading profits. Intel incurs costs of only $5 x$, for a net gain of $85 x$. The difference between Intel's gain and social loss is realized largely by AMD and its shareholders who, in this example, suffer a net loss of $98 x$. The loss to AMD might translate into an even larger gain to Intel if and to the extent that the loss raises AMD's cost of capital, making it harder to raise financial capital and harder to attract human capital through stock-based compensation. Permitting your employees to trade on your competitors' stock may be a socially inefficient, but privately profitable, strategy of raising rivals' costs. ${ }^{136}$ This does not mean that trading in stock substitutes on balance benefits Intel and its shareholders - because the game could easily devolve into a race toward the bottom. At the same time Intel executives are trading in AMD stock, AMD executives are presumably trading in Intel stock. If the numbers are symmetrical, then Intel and its shareholders suffer a loss of $98 x$ at the hands of AMD executives. Intel's overall loss is roughly the social costs of the practice. Can Intel eliminate this loss by prohibiting its executives from trading in AMD stock? No, because the trading that causes the loss is done by AMD, rather

134. This is most likely to be true when a firm's executive trades in a rival's stock. In cases of upstream and downstream privity, we might expect private contracting between the parties to limit this form of trading. See discussion infra notes 104-118 and accompanying text. The case of complementary products-Intel processor and Microsoft softwareactually falls between the two extremes. Losses suffered by one firm at the hands of executives at another firm that sells a complementary product may hurt the latter firm.

135. Social benefit: $90 x$ (trader value) $+2 x+1 x$ (more accurate $A M D$ price) $=93 x$. Social cost: $100 x$ (trading losses) $+5 x$ (decision distortion) $=105 x$.

136. Thomas G. Krattenmaker \& Steven C. Salop, Anticompetitive Exclusion: Raising Rivals' Costs to Achieve Power over Price, 96 YALE L.J. 209 (1986). 
than Intel, executives. Intel and AMD are trapped in a prisoner's dilemma game of reciprocally imposing negative externalities on each other.

The social costs in the above example are clearly artifacts of numbers we chose in illustrating the dynamics of substitute trading. Costs and benefits are both externalized; the magnitude of each term is an empirical matter about which we do not opine. As an analytic matter, it is possible that the benefits outweigh the costs. ${ }^{137}$ We doubt that this is the case, however, and most of the examples we use throughout will reflect our belief that the distortions caused by trading outweigh the incremental benefit of a more accurate stock price of the traded company. 138

\section{Trading by firms rather than employees.}

Earlier we noted that (1) insider trading by the firm was likely to be more efficient than insider trading by employees; (2) trading by the firm eliminated most of the decisional inefficiency associated with such trading; and (3) firms could be expected to establish a policy of trading only in those situations under which such trading was efficient.

The first of these results holds when we examine trading in stock substitutes: The firm is likely to be a more efficient trader-any trading the employee can do, the firm itself can likely do better. Trading by the firm, for example, eliminates the inefficiencies entailed in tying the purchase of managerial services to the exercise of trading rights. The second and third results, however, do not hold up when we examine trading in stock substitutes. There is no reason to expect that firms would trade only in those conditions when trading was socially desirable. Again, this is due to the fact that the trading loss to shareholders and the gains from more accurate stock pricing are both externalized. Assume, for example that Intel is considering a highvariance business strategy that will affect the price of a stock substitute and that the strategy imposes certain costs. These costs must be weighed against the profits realized from trading in a rival's stock and the possibility that trading will raise the rival's cost of financing. Intel's calculation ignores the losses to the rival's shareholders and the gains from more accurate stock pricing. Intel will pursue the strategy so long as the gains from trading and indirect gains from raising its rival's cost of capital exceed the costs of the strategy to Intel.

137. The intuition behind such a counterintuitive (and we believe unlikely) result would be that the prohibition on insider trading and possibly the recently enacted "fair disclosure" Regulation FD create large inefficiencies in pricing that are solved or at least mitigated through substitute trading. Our present belief that the market is "acceptably" efficient in pricing might change if a primary mechanism by which the market adjusts is eliminated.

138. But cf. supra at p. 268 (examples in which trading may either be efficient or indeterminant). 
It is possible that the welfare losses are increased if the firm, rather than the employees, trades in stock substitutes. This will be true if firm trading in stock substitutes is in itself inefficient, employee trading is more inefficient (as we assume), and the internalized losses to the firm of employee trading exceed firm gains. The inefficiency of employee trading puts a brake on a practice that is also inefficient but would otherwise be in the firm's self-interest. We noted earlier that, given a fixed amount of trading in stock substitutes, it is more efficient to have the firm, rather than employees, trade. But moving from employee to firm trading reduces internalized costs to the firm and makes it more likely that a socially inefficient practice will be adopted as in the firm's best interest. 139 By "firm's self-interest," we mean the self-interest of the firm and shareholders under conditions in which coordination with other firms is impossible.

The indeterminate efficiency effects of such trading at the firm level was pointed out long ago by Jack Hirshleifer. 140 Hirshleifer thought about the efficiency consequences of having inventors trade on their rival's stock. He concluded that such trading could lead to either too much or too little incentive to innovate. The additional profits from such trading might usefully increase the incentives to innovate, but there is also the possibility that it would create too much of an innovation incentive-by giving innovators a reward (profiting on their rival's loss) that was greater than the invention's contribution to social value. A parallel story can be told here. It is possible that allowing Intel to profit from trading on other high-tech firms would improve its incentive to do market research about future chip demand. Without such trading, Intel has an insufficient incentive to spend money to accurately forecast chip demand because it does not capture all the external benefits from producing such information. However, these trading profits may induce Intel to produce too much information from an efficiency standpoint.

If we assume that (due to patents and other factors) innovation is adequately rewarded absent substitute trading, substitute trading will systemically provide too much reward for innovation-at least that form of innovation that produces private information. Recall our earlier example of an

139. A numerical example may be useful here. Assume Intel is considering a risky project with an expected value, apart from trading profits, of $-10 x$. Trading profits on the project have an expected value of $15 x$ to Intel or its employees, and $-15 x$ to AMD shareholders. Giving Intel employees insider trading rights imposes a cost of $6 x$ on Intel. Trading by Intel employees (with profits recouped through adjustments in the wage contract) produces social costs of $16 x$ and provides Intel with a net return of $-1 x$. Intel chooses not to undertake the combination of project/trading. If the trading in AMD stock is done directly by Intel, social costs and costs incurred by Intel each decline by $6 x$. The project now imposes social costs of $10 x$ and provides Intel with a net return of $5 x$. The project and trading are now attractive to Intel.

140. Jack Hirshleifer, The Private and Social Value of Information and the Reward to Inventive Activity, 61 AM. ECON. REV. 561 (1971). 
investment in a risky chip architecture. The expectation of trading gains may turn a socially undesirable project into a privately lucrative project.

It would be wrong, of course, to single out the effects of substitute trading on investments in innovation. All investments or behavior that produces private information is favored. If substitute trading were unavailable, a company may find it most profitable to match a competitor's price. But a company may decide it is more profitable to purchase its competitor's stock and then announce that it will not match its competitor's price. In this example, substitute trading gains have an anticompetitive effect and, in the short run at least, reduce consumer welfare. In other cases, substitute trading may have an opposite effect. A company that would otherwise decide not to match a competitor's price might decide otherwise and recoup its lost profits through gains from shorting its competitor's stock. In still other cases, a company will find itself in the fortunate position of taking the otherwise profit-maximizing path and still trading on the result before it is announced. The common feature of these examples is that the possibility of gains from substitute stock trading has the potential to distort business decisionmaking. ${ }^{141}$

Indeed, seeing the externalizing effects of substitute trading calls into question the presumptive efficiency of "outsider" trading on nonpublic information more generally. In deciding whether to expend resources on information-gathering and then trade on nonpublic information about a company, an outside analyst-like the substitute trader-does not internalize all the costs and the benefits of such trading. A la Hirshleifer, the generic outside trader may have too much or too little incentives to trade. Manne's original internalization insight taken to its logical conclusion flips all our intuitions: Not only is insider trading (by the firm, we argue) presumptively efficient because of internalization, but all outsider trading (including substitute trading) is, if anything, presumptively inefficient.

So even if we have distinguished substitute trading from insider trading as being worthy of regulation, we still need to distinguish substitute trading from this more general category of outsider trading as being more worthy of regulation (or we would be driven to the regulation of outsider trading more generally). We think substitute trading is more problematic than outsider trading for two reasons.

141. To give an even more extreme and chilling example: Substitute trading may make it profitable for a firm intentionally to reduce its underlying profitability. As a theoretical matter, it is illuminating to consider an "Atlas Shrugged" scenario in which a firm (say, Microsoft) destroyed all of its productive capacity on a particular day but profited immensely by selling another firm's stock short. It has long been understood that traditional insider trading might give unfaithful fiduciaries an incentive to reduce the underlying profitability of their own firm (to profit from short selling), but substitute trading raises the possibility that faithful managers would intentionally reduce the profitability of their firm in order to further their shareholders' ultimate interest. 
First, the substitute trader can more easily than the outside trader take nontrading actions that affect the profitability of the traded firm. These costs are apt to be much larger than the costs an analyst incurs to acquire information.

Second, the traded firm may have less ability to protect itself from inefficient substitute trading. Firms can preempt outsider trading by releasing nonpublic information on which analysts trade to the market as this information comes into existence. There is an increasing trend for firms to voluntarily do this by, for example, releasing weekly sales data to the market. ${ }^{142}$ When traded firms can preempt outsider trading by public disclosure, then the firm's failure to do so can be seen as implicitly giving the outsider permission to trade on the nonpublic information. Even though the outsider does not internalize the costs and benefits of such trading, the traded firm's prior decision of whether to release the nonpublic information goes a long way toward recreating an internalization-type argument with regard to outsider (analyst) trading.

The decision of the firm not to preempt the outsider and the decision of the outsider to trade jointly tend to internalize the costs and benefits of such trading. Substitute trading, however, stands on a different footing than outsider trading because the traded firm often itself is not privy to nonpublic information-and it does not have the option of preempting the substitute trading by prior disclosure. Compaq might not know that Intel has experienced greater than expected chip demand. Texaco may not know that Penzoil has discovered a document that will win (or lose) the case. Genentech may not know that Chiron has cloned Human Growth Hormones. Substitute trading is accordingly more worthy of regulation than outsider trading by analysts because substitute traders have a greater ability to take non-trading actions to hurt the traded firm, and the traded firm has less ability to protect itself from the externalized harms of such trading.

142. In October 2000, the SEC promulgated a new rule-Regulation FD-that requires corporations to divulge material information about their performance to everyone at the same time, thereby depriving analysts of the informational advantage they previously enjoyed. See Jonathan Fuerbringer, When Companies Talk, Who Gets to Lisien?, N.Y. TmES, Oct. 20, 2000 , at $\mathrm{Cl}$. However, even before this rule came into effect, companies were already moving in the direction of broader disclosure. Companies, including big corporations such as Intel, for example, were already disclosing corporate performance information to the general public. See Kenneth Aaron, Companies, Investors Play by New Rule, TIMES UNION (Albany, NY), Sept. 26, 2000, at E1; Fuerbringer, supra; SEC Fair Disclosure Proposals Meet with a Mixed Reaction, INVESTOR REL. BuS., Jan. 10, 2000, at 1. A news report stated that "broadcasting of Wall Street analysts' meeting on the Internet, what is known as Webcasting, is already becoming standard procedure and will grow, as will public access to conference calls that companies use to brief analysts." Fuerbringer, supra. The National Investor Relations Institute estimated that " $86 \%$ of its member companies that hold earning conference calls allowed individual investors to listen in, up from $29 \%$ two years ago. About 74\% let the news media listen in, up from 14\%." Id.

Admittedly, outsider trading by public disclosure is not a panacea. At times, the firm will have a legitimate business reason for not disclosing-such as in SEC v. Texas Gulf Sulphur Co., 401 F.2d 833, 854 (2d Cir. 1968), where the firm wanted to be able to buy land on the cheap. 


\section{Trading on privity substitutes (i.e., customers, suppliers, or joint venturers).}

In the next two sections, we will distinguish between a firm trading in "privity" and "non-privity" substitutes. By a privity substitute, we mean firms that have a contractual relationship with the trading firm-including the trading firm's customers, suppliers and co-venturers. By a non-privity substitute, we mean firms that do not have a contractual relationship with the trading firm (but nonetheless may have correlated fates) -including the trading firm's rivals and complementors. The privity/non-privity distinction is important because it is more likely that firms in privity with one another will be able to contract expressly or implicitly to internalize the otherwise externalized costs and benefits of substitute trading-by the firms or their executives.

Analytically, the question of whether a particular firm would contract to allow another firm to trade on the basis of material nonpublic information is analogous to the question of whether a firm would contract to sell trading rights to its own managers or to a third-party investment firm. ${ }^{143}$ Because the social costs and the social benefits are dominantly visited upon the trading and the traded firms, an arm's length contractual indication that the two firms find such trading to be beneficial is strong evidence that the agreement should be respected. Indeed, the case for respecting such contracts is in two related respects greater than the case for respecting a firm's decision to allow its employees to engage in traditional insider trading. First, granting a supplier or a customer the right to profit from trading on nonpublic information does not raise self-dealing concerns that would tend to undermine our confidence that the ceding firm actually benefits from the trading. Second, while a firm may be a more efficient trader than its employees (as we argue earlier), it may not be a more efficient trader than another firm. One firm may have special insight into the prospects of related companies-not only because the prospects of the related companies may be tied to the prospects of the trading firm, but because the trading firm may have proprietary data as to how the traded firm's products stack up against it's competition. For example, Compaq may have better knowledge than Intel as to how an Intel processor fares against a rival processor.

What would a privity contract that allowed such trading look like? A supplier that granted a downstream purchaser the right to trade its stock on the basis of nonpublic information recoups the trading losses of its shareholders through adjustments in the supply contract. In the above example, Ford may pay more for a prototype that offered it the possibility of trading profits on its supplier's stock. The adjustment mechanism would in a sense be the same as that which would reduce the salary of employees who are given rights to

143. See Carlton \& Fischel, supra note 5, at 874 ("[W]ith respect to insider trading, the actions of a key executive of a firm do not differ in principle from those of a key supplier to the firm."). 
traditional insider trading. 144 The analytics of upstream or downstream relationships are the same whether or not the supplied good or service is secret or represents cutting-edge technology: All that is required is that the relationship provides the possibility of trading profits. We began this paper with the example of an Intel executive having information as to the sales of personal computers (downstream relationship) and sales of semiconductor manufacturing equipment (upstream relationship). The upstream supplier's price might be higher or the downstream customer's price might be lower to offset the losses the investors in these firms would suffer if Intel contracted for the right to profit from trading on nonpublic information. ${ }^{145}$

Even in a world of perfect contracting, there may be cases in which information rights are given without adjustment in the price of supplies. A thinly traded company with hard-to-value technology may believe its stock is undervalued and, as a result, find it hard to raise capital directly through the equity markets, or human capital through the grant of stock options to key employees. Such a company may welcome supplier purchases that support its stock price; the fact that such purchases may cement relationships between itself and its new stockholders and therefore strengthen the supply relationship may be seen as an added bonus.

Of course, there will still be many situations in which trading of one firm's stock by its privity substitute firms (or those firms' employees) will not be jointly beneficial. In some cases, a firm may find it advisable to contract with downstream or upstream firms to limit the ability of those firms (and executives in those firms) from using nonpublic information to profit from trading in its stock. For example, the company that produces assembly line manufacturing equipment for Ford may require Ford to agree that neither it nor its employees will use information about the equipment to profit from trading that company's stock. There is anecdotal evidence that such contractual limitations on the use of proprietary data are common, at least in Silicon Valley. ${ }^{146}$ Indeed, we conjecture that firms would only rarely agree to grant unlimited trading rights to a privity substitute. Recalling Carlton and Fischel's realistic hypothetical of a supplier breaching a contract where one firm profited by short selling another, we believe that contracts that expressly granted substitute trading rights would not grant the right of one firm to short the stock of a privity substitute.

144. If Ford itself does not trade but its employees do trade, the "correct" adjustment would be two-fold: a higher price for the good tied to lower explicit wages. In practice, however, we suspect (based on our earlier quasi-dominance conjecture) that Ford would, absent self-dealing inefficiencies, be the more efficient trader.

145. Alternatively, the good might be expected to bring trading gains as well as trading losses, with no net effect on pricing. For example, a customer of Intel such as Compaq might expect that it would benefit as much from the information it learns about Intel as Intel benefits from the information it learns about Compaq.

146. See also supra pp. 264-65 (discussing current corporate practice). 
4. Trading on non-privity substitutes (i.e., rivals and complementors).

In theory, firms that are not in privity might contact with each other to reach an efficient policy with respect to trading in each other's stock. For example, if, as we suggest, substitute trading is apt to be inefficient but (in most cases) legal, AMD and Intel might contract with each other to prohibit crosstrading in each other's stock-at least such trading that makes use of material nonpublic information. The companies might also contract to prohibit employee trading in the other company's stock. In practice, this sort of contract would raise nearly insurmountable information, monitoring and transaction costs. Among other things, companies would have to estimate and value the future prospect of substitute trading in either direction; and companies would find it nearly impossible to monitor whether the other company or its employees were complying with a trading ban (on material nonpublic information).

\section{POLICY RECOMMENDATIONS}

Our analysis suggests substitute trading is apt to be inefficient and that in non-privity situations we cannot rely on companies to contractually limit such trading to those cases in which trading enhances welfare. For policy purposes, our analysis raises four sets of questions: (1) Is it economically or practically feasible to determine the stock substitutes for any given company? 2) What disclosure rules would be appropriate for regulators, investors and employees? (3) What substantive changes in the law might be required and how might they be implemented? and 4) What cognate securities restrictions are affected by trading in stock substitutes?

\section{A. Defining Stock Substitutes}

The first step in regulating or even studying the real world practice of trading in stock substitutes is to come up with a workable definition of stock substitute, that is, a definition that can produce for each company a set of companies that serve as stock substitutes. This is a daunting task, because as in antitrust market definition, the definition of trading substitutability is one of degree; in some sense, the movement of virtually every stock is correlated with virtually every other stock. We outline below a set of definitions and compilation rules that we believe will produce a list of the most significant stock substitutes for most companies. Our approach will require virtually no additional social resources, and can easily be incorporated into the disclosure regime we recommend. 


\section{Suppliers and customers.}

Rule SK currently requires a firm to report in its Form 10-K filing (as part of its "description of business") a customer name "if sales to the customer by one or more segments are made in an aggregate amount equal to $10 \%$ or more of the registrant's consolidated revenues and the loss of such customer would have a material adverse effect on the registrant and its subsidiaries taken as a whole." 147 We would expand this rule to also require firms to identify those firms that supply goods or services representing more than $10 \%$ of the firm's non-labor expenditure. The disclosure of a firm's major customers and suppliers would go a long way toward identifying an important class of privity substitutes-i.e., those external firms to which the disclosing firm is vulnerable. These rules would not, however, identify the class of firms that are vulnerable to the disclosing firm. To understand why this is the case, imagine a small firm that sells a high proportion of its output to a large company such as Intel. The firm might well be a source of trading gains for Intel or its employees. Its fortunes might be tied to Intel's fortunes, or purchasing decisions by Intel. Any system that required disclosure of purchases in stock substitutes would want to require Intel or its employees to disclose purchases in the smaller firm. A waivable default prohibition on trading in stock substitutes might require Intel to include this firm on a list of "prohibited investments" to its employees-at least under circumstances in which the employees could not trade in Intel stock.

The difficulty is that the smaller firm would not be listed in Intel's SK because it did not account for $10 \%$ of Intel's supplies. However, the smaller firm would list Intel as a 10\% customer on its SK. The SEC could at virtually no cost send Intel a computer-produced list of all companies that listed Intel in their SK; these companies, together with the companies Intel lists in its SK, could constitute a list of suppliers and customers for which substitute trading might prove profitable.

\section{Rivals.}

Deriving a list of non-privity substitutes (chiefly, rivals and complementors) is difficult because it requires a disclosing firm to identify firms with whom it does not have contractual arrangements. Rule SK currently does not require firms to disclose their rivals' identities-unless the rival is a "dominant" firm in the industry. 148 However, a list could easily be compiled at the administrative level by requiring each firm to list the four digit SIC code for

147. 17 C.F.R. $\$ 229.101$ (c)(1)(vii) (2001).

148. See 17 C.F.R. $\$ 229.101$ (c)(1)(x) (2001) ("Generally, the names of competitors need not be disclosed .... Where, however, the registrant knows or has reason to know that one or a small number of competitors is dominant in the industry it shall be identified."). 
its industry; the SEC could produce a list that for each firm would contain the other firms with that same SIC classification.

\section{A quantitative definition of stock substitutions.}

The lists described above-of customers, suppliers, rivals and complementors-are intended to tell us which firm is a substitute for another. There is another, and in some ways superior, method of making that determination: The SEC might determine, for each company, a list of other companies whose abnormal returns have a statistically significant correlation with the abnormal returns of the reporting firm. The abnormal returns of a stock are simply the changes in the stock's value on a particular day that cannot be explained (using the Capital Asset Pricing Model) by general market movements. ${ }^{149}$ This statistical correlation alternative to defining a firm's stock substitutes would be to regress the abnormal returns of other publicly traded firms on the abnormal returns of the reporting firm (plus a constant) to see if there is a statistically significant positive or negative correlation. Under the semi-strong form of the Efficient Capital Markets Hypothesis, this regression would tend to show whether publicly disclosed information that unexpectedly moved the reporting company's stock also tended to move the price of another firm's stock. As emphasized above, particular kinds of information might induce positive correlations between two rivals' values, while other kinds of information might induce negative correlations between the rivals' values. Hence, the foregoing regression might be under-inclusive--because some firms on average may have no average positive or negative correlation, even though, for insiders, particular types of information could be expected to have predictable positive or negative effects. ${ }^{150}$ While this statistical alternative would require the estimation of many alternative regressions-one for every other publicly traded firm-this task could easily be centralized and performed by the SEC or its designate. The individual regressions are trivial, and while there are thousands of permutations that would need to be estimated, the job could be handled by a single individual with a medium-sized workstation.

149. Abnormal returns and similar "CAPM" regressions are discussed in RONALD J. Gilson \& BernaRd S. BlaCK, (SOME OF) the Essentials of FINANCE and INVESTMENT 124,194 (1993).

150. See supra text accompanying notes 14-19 (discussing event studies showing that one firm's unexpected increase in costs tended to produce negative correlation in its rival's stock price, while one firm's unexpected increase in demand tended to produce a positive correlation in its rival's stock price). One way the aforementioned regression might be made less under-inclusive would be to test whether the absolute value of another firm's abnormal returns was correlated with (the absolute value of) the abnormal returns of the reporting firm. 


\section{Other possibilities.}

It would be easy to supplement lists compiled from the above-described sources. For example, the SEC could compile, for every company within a four digit SIC code, a list of suppliers and customers listed by other companies within that same code. This would produce, as a potential stock substitute for Compaq, a company such as Motorola, which produces processors for Apple (but not Compaq).

We might finally require reporting firms to disclose the names of all other firms whose activities (success or failure in the market) are likely to materially affect the profitability of the reporting firm. This list could be combined with a list of firms that had named the reporting firm in this fashion to form a qualitative set consisting of possible stock substitutes.

\section{B. Disclosure Rules}

\section{Disclosure of firm policy.}

An appropriate disclosure policy would require firms to state whether they had (1) granted or denied permission to their own employees the right to trade substitute stocks (on the basis of material nonpublic information); or (2) opted to retain the right to trade the stock of specific related firms (on the basis of material nonpublic information). ${ }_{151}$

This disclosure rule would clarify the legality of trading for employees. As noted above, the law governing employee trading in stock substitutes in the absence of contractual permission or prohibition is unclear. Our disclosure policy would force each firm to outline its policy and in that manner remove the ambiguity. Under existing law, employee trading in stock substitutes is illegal in firms that explicitly ban such trading and legal in firms that allow such trading. Our disclosure rule would simply force firms to announce their policy.

Our disclosure rule would also provide information to investors. As noted above, in the absence of a coordination rule, even inefficient stock substitute trading might well be in the interests of shareholders. But such employee trading may dramatically increase compensation to management; investors therefore should know whether management receives trading rights. Investors

151. This disclosure rule would represent a kind of "affirmative choice" defaultforcing the disclosing firm to make an affirmative choice or face a penalty for remaining silent. Alternatively, one might argue in favor of a default prohibition (which would infer from a reporting firm's silence that it had not granted trading permission to itself or its employees). But for clarity sake, we prefer the affirmative choice default as it eliminates the need of reading the entire disclosure document to learn whether the firm has opted out. 
may also want to know whether, and to what extent, such trading constitutes a component of investment returns.

Perhaps most importantly, disclosure will provide policymakers with information as to industry practice.

\section{Disclosure of trades.}

While ex ante disclosure of trading policy will provide important information to policymakers and investors, ex post disclosure of trading results would provide much more useful information. Rule $16 \mathrm{~b}$ currently requires certain statutorily defined insiders and major stakeholders to disclose, ex post, their trading on their firm's own stock. Rule 16 could be amended to require ex post disclosure of their trading-how many shares and at what price-on stock that had been previously identified by their employer as a stock substitute. Disclosure of such trading (whether or not on the basis of material nonpublic information) would help assess whether this form of compensation was excessive in relation to the reduction in the employee's salary. It would also give the firm, its shareholders, and policymakers a much greater insight into whether the potentials for substitute trading abuse (chiefly, externalized negative effects, deleterious internal conflicts of interest and uncompensated self-dealing by managers) were empirically important.

The ex post disclosure rules described above could be modified in one of two ways. First, to the extent disclosure is intended to guide policymakers, the rules might be applied only to a sampling of firms or industry. On the other hand, at least in technology industries, where information might be located below top management, disclosure could be extended to a greater subset of employees than those covered by $16 \mathrm{~b}$.

\section{Disclosure of the implicit value of stock trading as executive compensation.}

If a firm does grant its employees the right to profit from trading on its privity and non-privity substitutes (and duly reports it as required in the previous section), it might be worthwhile to also require the firm to estimate the value of the trading right as part of the executive compensation reporting requirement. ${ }^{152}$ As detailed above, a firm/employer has an absolute right to

152. Currently, detailed rules govern the disclosure of executive compensation. See 17 C.F.R. $\$ 229.402$ (2000). Corporations are required to disclose the compensation of "(i) [a]1l individuals serving as the registrant's chief executive officer or acting in a similar capacity during the last completed fiscal year... regardless of compensation level; (ii) the registrant's four most highly compensated executive officers other than the CEO," and other individuals as well in some circumstances. Id. $\$ 229.402$ (a)(3). "Compensation," is defined broadly to include "all plan and non-plan compensation." Id. $\$ 229.402(\mathrm{a})(2)$. Therefore, under the current rules, any arrangement- "whether or not set forth in any formal 
prohibit such trading under O'Hagan. A firm's failure to prohibit the trading can give rise to huge potential profits for the manager. Such profits were vividly illustrated by the managerial profits reaped by a Cisco manager. ${ }^{153}$ If Henry Manne is correct that granting managers the right to trade on inside information results in reduced salaries, ${ }^{154}$ then it is important for this trading option to be valued so that the market can better value whether managers are being appropriately compensated.

But contrary to Manne's argument, we believe it will be exceedingly difficult for a firm to accurately price the substitute trading option. We would therefore insulate such disclosure from any private litigation and would only allow the SEC to find a disclosure violation if the firm did not exercise due diligence in making their estimate. To the extent that the substitute trading rights had a seasoned track record, the firm would be required to relate the expected future value to the demonstrated past profitability on such trades.

\section{Changes in Substantive Law}

The proposals outlined thus far would leave the decision to allow substitute trading with the firm that possesses, or whose employees possess, material nonpublic information. However, our analysis suggests that substitute trading is apt to be an inefficient practice. The costs and gains of substitute trading are externalized, and there is likely to be too much substitute trading. This Article is the first to examine substitute trading in any length and the first to offer any thoughts on the efficiency of such trading. We are too realistic to believe that a single paper is likely to (or even should) lead to fundamental change in the securities law. However, the direction in which our analysis points is clear: Serious consideration ought to be given to placing limits on substitute trading. Our analysis, if confirmed, suggests that corporate trading on material information in a stock substitute should be illegal unless the trading firm had permission from the firm whose stock was being traded. ${ }^{155}$ The rule would

documents"-involving, among other things, cash, stock, stock options, stock appreciation rights, warrants, convertible securities and similar instruments needs to be disclosed. Instructions to Items 402 (a)(3), 17 C.F.R. $\$ 229.402$ (2000).

One wrinkle to the disclosure rules is that corporations may exclude some executive officers from the disclosure requirement if their compensation in a particular year is "unusual," i.e., when "the distribution or accrual of an unusually large amount of cash compensation (such as a bonus or commission) ... is not part of a recurring arrangement and is unlikely to continue." Id. Nonetheless, the rules make it quite clear that exclusion is appropriate only in "limited circumstances." Id. Furthermore, trading in stock substitutes, to the extent that it occurs in some industries, cannot fairly be said to be outside of "a recurring arrangement" that "is unlikely to continue." Id.

153. See Simpson \& Thurm, supra note 84; see also supra Part III.

154. HeNRY G. MANNE, INSIDER TRAdING AND THE STOCK MARKET 138-41 (1966); see also Carlton \& Fischel, supra note 5, at $862-83$ (analyzing insider trading as a form of compensation scheme).

155. An alternative approach would be to adopt a variant of the pretrade disclosure 
give each firm a negative property right that would enable the firm to prevent trading in its own stock. 156 Presumably, the firm would grant trading rights in those cases in which the trading is on balance efficient. Employee trading rights would follow from employer rights and the rule outlined in Part V.B, above. Employees could trade if employers could trade and if their employers had announced a policy which permitted such trading.

While granting the traded firm a negative property right to block substitute trading is theoretically more consistent with the goal of finding a decisionmaker who internalizes the costs and benefits of substitute trading, our less ambitious recommendation that the trading firm must merely disclose that it or its employees might engage in future substitute trading is likely to move us toward a more efficient equilibrium. Substitute trading by firms themselves may not be a large risk because of the huge liquidity demands discussed above, and we predict that the majority of firms would not grant their employees unrestricted rights to engage in substitute trading. ${ }^{157}$

\section{Other Possible Changes in Substantive Law}

\section{Section 10(b) and Rule 10b-5.}

Our analysis also has implications for other aspects of Section $10(\mathrm{~b})$ and Rule 10b-5. One of these implications has been discussed in Part IV.A, above. Our analysis of "traditional" insider trading suggests that the present prohibition be replaced by a default prohibition waivable by the firm. The firm would also be given the right to allow its employees to trade. Because we conclude that trading by employees is unlikely to be efficient and management approval of such trading raises self-dealing issues, we would subject employee trading to the scrutiny afforded under the duty of loyalty standard.

A second implication revolves around the "material misstatement" clause of Section 10(b). As is perhaps obvious, a material misrepresentation by a corporation or its officers may affect the stock price of other companies. In a world in which substitute trading becomes popular, one of the purposes of such misrepresentation may be to affect the prices of other companies' stocks. A

system that Jesse Fried has proposed with respect to other forms of insider trading. See Fried, supra note 107 , at 305-92.

156. A more aggressive proposal would be to extend the negative property right to all trading on material nonpublic information. This prohibition would include trading done by analysts or other outsiders. See Ian Ayres \& Stephen Choi, Internalized Outsider Trading (unpublished manuscript, on file with authors).

157. Subjecting such permission to self-dealing scrutiny and potentially pricing the value of this trading right as a component of executive compensation may further deter the grant of such trading permission. 
person who makes a misstatement about one firm and then profits from trading on another firm should face civil liability.

The predictable tendency of related firms' stock prices to move based on particular pieces of information also suggests a basis for extending fraud on the market liability to what we call "fraud on a substitute." Imagine that a firm (through its managers) intentionally misrepresents that it is about to win an important patent race that it has been engaged in with a particular rival. The impact of the misrepresentation predictably would be to raise the stock price of the misrepresenting firm and to reduce the stock price of its rival. Individuals who purchased shares of the misrepresenting firm after the misrepresentation had been made but before its falsity had been public would (given certain preconditions) have a strong "fraud on the market" case against the firm for having purchased at too high a price. ${ }^{158}$ But what about the shareholders of the rival who sold during the interim period in which the rival's stock price was artificially depressed? The same logic that undergirds "fraud on the market" liability suggests that the firm or person making a misrepresentation should also be liable for "fraud on a substitute" for the losses suffered by shareholders of other companies whose stocks are affected by the misstatement. ${ }^{159}$

Finally, adoption of any substantive limitations on stock substitute trading will require a (somewhat obvious) amendment to the definition of what constitutes material information. In traditional insider trading, the company whose stock is traded is the same company that is trading or whose employees are trading. When stock substitutes are traded, it is necessary to determine whether information is material with respect to the trader's company or the traded company. The correct rule, of course, is that materiality should be defined with respect to the company whose stock is traded. Thus, for an executive of Ford who is trading on a supplier stock, any restrictions on the trade would require that the information upon which the trade is based be material to the supplier.

\section{Rule 14e and Section 16(b).}

Our analysis also has implications for at least two other sections of the securities laws, Rule 14e-3 and Section 16(b). Presently, 14e-3 prohibits any person from using nonpublic information traceable to a party making a tender offer from purchasing the stock of the target of the tender offer. ${ }^{160}$ But it does

158. See Basic v. Levinson, 485 U.S. 224 (1988); Ayres, supra note 119, at 995.

159. See Semerenko v. Cendant Corp., 223 F.3d 165, 174-78 (3d Cir. 2000) (concluding that a misrepresentation by a merger partner may support civil liability to shareholders of other partner to merger if, inter alia, there is a sufficient nexus between misrepresentation and loss).

160. 17 C.F.R. $\$ 240.14 \mathrm{e}-3(2000)$. "Rule $14 \mathrm{e}-3(\mathrm{a})$ is a disclosure provision. It creates a duty in those traders who fall within its ambit to abstain or disclose, without regard to whether the trader owes a pre-existing fiduciary duty to respect the confidentiality of the 
not currently prohibit any individual from profiting on this nonpublic information by trading on firms that are related to the target of the tender offer. Thus the same information that cannot be used to purchase the target of a tender offer can be used to purchase other firms in the same industry-even though in many cases it will be easy to predict how the merger announcement will impact the value of the legally traded firm. ${ }^{161}$ The same rationale that supports Rule 14e-3 may support extending its reach to stock substitutes.

Section $16(b)$ requires insiders to surrender profits realized from short-term investments in their company's securities; the rule is designed as a prophylactic measure, on the assumption that such profits are likely to be due to nonpublic material information. If future analysis supports our conclusion that substitute trading is apt to be inefficient, and limitations on that trading are imposed, consideration should be given to extending the reach of $16(\mathrm{~b})$ disgorgement to trading in stock substitutes.

At present, we do not advocate substantive limits on trading in stock substitutes; even if limits are imposed, it is not clear that the above-described extensions of the limits are desirable. It may be, for example, that the aggressive role of the plaintiff's bar, together with the transaction costs involved, make even the current administration of civil penalties for material misstatements excessive. If that is the case, extension of $10(\mathrm{~b})$ liability to shareholders of other firms, while analytically appealing, is unnecessary and socially wasteful. Strong objections can also be made to extension of $14 \mathrm{e}-3$ and 16(b) liability. 162 Our central point, however, remains: In an increasingly sophisticated economic marketplace, the securities law must be concerned not only with transactions in a given stock but in substitutes for that stock.

information." United States v. O'Hagan, 521 U.S. 642, 669 (1997) (quoting United States v. Chestman, 947 F.2d 551, 557 (1991) (en banc)) (emphasis in original).

161. In some cases, an industry participant may expect the traded firm to rise in value due to oligopolistic pricing or the now-increased prospect that the traded firm will itself be acquired; in other cases, increased competition by the soon-to-be-combined firms may create an expectation that the traded firm will fall in value.

162. Rule 14e-3 was adopted in response to the decision in Chiarella v. United States, 445 U.S. 222 (1980), in which an employee of a financial printer traded on information in the possession of his employer. The facts in Chiarella would now give rise to liability under the misappropriation doctrine; this is true for most $14 \mathrm{e}-3$ cases. Rule 14e-3 still has some residual power; for example, it prohibits an "innocent" eavesdropper from trading on an upcoming tender offer. The Rule may perhaps be justified on efficiency grounds: Tenders are an important means of removing entrenched but underperforming management, and trading in advance of a tender may raise the price the offeror must pay to acquire control. Trading on a stock substitute affects the tender offer only derivatively (for example, to the extent an increase in stock substitute price increases the price of the subject of the tender offer). In other respects, trading on a stock substitute in advance of a tender seems similar to "garden variety" outsider or analyst trading. It is unclear, therefore, whether there is an efficiency grounds to ban such trading. See supra Part IV.C (discussing the efficiency effects of analyst or outsider trading). 


\section{CONCLUSION}

Under current law, employees cannot use material nonpublic information to trade in their employer's stock; an employer cannot use such information to trade in its own stock. In many cases, however, that same information can be used to profitably trade on the stock of other companies. Employers may trade in stock substitutes without legal restrictions. The treatment of employees is less clear. The opportunities for profit in such trading seem substantial, and there is evidence that such trading is common, at least among employees.

Surprisingly, our analysis suggests that trading in stock substitutes is apt to be less efficient than traditional insider trading. Costs and benefits of traditional insider trading are apt to be internalized to the firm permitting or undertaking such trading; costs and benefits of trading in stock substitutes are externalized. There is no reason to think that an efficient amount of trading will occur, and under plausible assumptions, there will be too much trading in stock substitutes.

We suggest ways in which the stock substitutes for a given company can be compiled at virtually no cost and recommend a set of ex ante disclosure rules for firms and ex post disclosure rules for persons trading in stock substitutes. The disclosure rules should clarify the law for employees, and provide valuable information for investors and policymakers. We also describe substantive legal changes that might limit trading in stock substitutes and describe changes in related provisions of the securities law. We hold off recommending adoption of these substantive rule changes until more is learned about the extent of trading in stock substitutes and the policymaking community has a chance to respond to our analysis.

Finally, while this Article has focused primarily on the legal implications for informational trading substitutes, along the way we have contributed to traditional insider trading theory more generally. Our thought experiment of a hypothetical auction suggests that firms will often be better placed to trade on insider information than their employees, because firm-level trading of its own stock does not give rise to the perverse incentive effects of managerial insider trading. This quasi-dominance result suggests that, under a default regime, implicit or explicit agreements allowing managers to trade their own stock (on the basis of material nonpublic information) should be strictly scrutinized for both procedural and substantive fairness as a suspect self-dealing transaction. 